\title{
Five-Coordinate Tungsten(VI) Phenylimido Alkylidene Complexes and Isolated Precursors, Containing a Chelating Arylamine Ligand: Molecular Structure of $\mathrm{W}\left(\mathrm{C}_{6} \mathrm{H}_{4} \mathrm{CH}_{2} \mathrm{NMe}_{2}-2\right)\left(=\mathrm{CHSiMe}_{3}\right)\left(\mathrm{CH}_{2} \mathrm{SiMe}_{3}\right)(=\mathrm{NPh})$
}

\author{
Paul A. van der Schaaf, ${ }^{\dagger}$ David M. Grove, ${ }^{\dagger}$ Wilberth J. J. Smeets, ${ }^{\ddagger}$ \\ Anthony L. Spek, ${ }^{\ddagger}$ and Gerard van Koten ${ }^{*} \dagger$ \\ Department of Metal-Mediated Synthesis, Debye Institute, and Laboratory of Crystal and \\ Structural Chemistry, Bijvoet Center for Biomolecular Research, Utrecht University, \\ Padualaan 8, $3584 \mathrm{CH}$ Utrecht, The Netherlands
}

Received April 20, $1993^{\circ}$

\begin{abstract}
With monoanionic 2-[(dimethylamino)methyl]phenyl, an aryl ligand in which a potentially chelating tertiary amine group is present, five-coordinate tungsten(VI) phenylimido alkylidene complexes and their alkyltungsten(VI) precursor complexes have been isolated. For example, use of this potentially intramolecular coordinating ligand makes it possible to synthesize the tungsten(VI) alkylidene complex W $\left(\mathrm{C}_{6} \mathrm{H}_{4} \mathrm{CH}_{2} \mathrm{NMe}_{2}-2\right)(=\mathrm{CHSiMe})\left(\mathrm{CH}_{2} \mathrm{SiMe}_{3}\right)(=\mathrm{NPh})(5)$ via a simple one-step reaction from an easily accessible trialkyltungsten phenylimido precursor. Introduction of $\pi$-electron donor substituents, such as tert-butoxide and 3,5-dimethylphenoxide ligands, allows isolation and characterization of the respective alkylidene precursor complexes; e.g. W $\left(\mathrm{C}_{6} \mathrm{H}_{4} \mathrm{CH}_{2} \mathrm{NMe}_{2}-2\right)\left(\mathrm{CH}_{2} \mathrm{SiMe}_{3}\right)_{2}(=\mathrm{NPh})\left(\mathrm{OCMe}_{3}\right)(7)$. Complex 7 is unstable at elevated temperatures and decomposes via intramolecular $\mathrm{H}_{\alpha}$-abstraction reactions. Reaction of 5 with tert-butyl alcohol affords a 1,2-addition of the alcohol at the alkylidene function and subsequent formation of 7; the same reaction with triphenylsilanol results in the instantaneous formation of the new alkylidene complex W $\left(\mathrm{C}_{6} \mathrm{H}_{4} \mathrm{CH}_{2} \mathrm{NMe}_{2}-2\right)\left(=\mathrm{CHSiMe}_{3}\right)(=\mathrm{NPh})\left(\mathrm{OSiPh}_{3}\right)(6)$, in which the alkyl group is replaced by the silanol group. The analytically pure alkylidene complexes 5 and $\mathbf{6}$ are inert toward linear olefins but react with aldehydes and ketones in a Wittig-type reaction. The olefin products of the reaction with the aldehydes are obtained as a cis/trans mixture in which the trans isomer is predominant. With cyclic olefins very fast ring opening metathesis polymerization (ROMP) reactions take place; cyclic olefins in which two double bonds are present, such as norbornadiene and dicyclopentadiene, produce cross-linked polymers, whereas reaction with norbornene leads to selective formation of cis-polycyclopentenamers. The five-coordinate structure of 5 that results from intramolecular $\mathrm{W}-\mathrm{N}$ coordination has been proven in the solid-state (X-ray diffraction) and in solution (NMR) spectroscopy). Crystals of 5 are monoclinic, space group $P 2_{1} / a$ with unit-cell dimensions $a=17.950(3) \AA, b=16.633(4)$ $\AA, c=19.472(4) \AA, \beta=115.48(2)^{\circ}$, final $R=0.0661$, and $R_{\mathrm{w}}=0.0653$.
\end{abstract}

\section{Introduction}

Recently, we reported the use of chelating ligands containing tertiary amine substituents in organotantalum(V) chemistry. ${ }^{1}$ With bidentate arylamine ligands, e.g. $\mathrm{C}_{6} \mathrm{H}_{4} \mathrm{CH}_{2} \mathrm{NMe}_{2}-2$, stable aryltantalum(V) complexes in which two alkyl groups are present were synthesized. Upon heating, these complexes gave rise to intramolecular $\mathrm{C}-\mathrm{H}$ activation reactions with subsequent formation of an alkane and of a tantalaazacyclopropane species having intramolecular $\mathrm{Ta}-\mathrm{CN}$ coordination. With the terdentate

* To whom correspondence should be addressed.

$\uparrow$ Debye Institute.

* Bijvoet Center for Biomolecular Research.

- Abstract published in Advance ACS Abstracts, September 1, 1993.

(1) (a) Abbenhuis, H. C. L.; Grove, D. M.; van Mier, G. P. M.; Spek A. L.; van Koten, G. J. Chem. Soc., Chem. Commun. 1989, 1581. (b) Abbenhuis, H. C. L.; Grove, D. M.; van Mier, G. P. M.; Spek, A. L.; van Koten, G. Recl. Trav. Chim. Pays-Bas 1990, 109, 361. (c) Abbenhuis, H C. L.; Grove, D. M.; van der Sluis, P.; Spek, A. L.; van Koten, G. Recl. Trav. Chim. Pays-Bas 1990, 109, 446. (d) Abbenhuis, H. C. L.; Feiken, N.; Haarman, H. F.; Grove, D. M.; Horn, E.; Kooijman, H.; Spek, A. L.; van Koten, G. Angew. Chem., Int. Ed. Engl. 1991, 30,996. (e) Abbenhuis, H. C. L.; Feiken, N.; Grove, D. M.; Jastrzebski, J. T. B. H.; Kooijman, H.; van der Sluis, P.; Smeets, W. J. J.; Spek, A. L.; van Koten, G. J. Am. Chem. Soc. 1992, 114, 9773. (f) Abbenhuis, H. C. L.; van Belzen, R.; Grove, D. M.; Klomp, A. J. A.; van Mier, G. P. M.; Spek, A. L.; van Koten, G. Organometallics 1993, 12, 210.

0276-7333/93/2312-3955 $\$ 04.00 / 0$ aryldiamine ligand $\mathrm{C}_{6} \mathrm{H}_{3}\left(\mathrm{CH}_{2} \mathrm{NMe}_{2}\right)_{2}-2,6$ (=trans-pincer), tantalum $(\mathrm{V})$ alkylidene complexes with interesting properties were made. For example, a trans-pincer tantalum alkene adduct was isolated from the rearrangement reaction of a trans-pincer tantalum(V) alkylidene complex with ethene. The same reaction with a derivative of the alkylidene complex containing a tert-butoxide group led to the formation of a stable tantalacyclobutane complex.

Since it is known that tungsten(VI) alkylidene complexes are more reactive in metathesis reactions with linear and cyclic olefins than related tantalum(V) species, we became interested in the use of this type of chelating ligand in the field of tungsten(VI) alkylidene chemistry. ${ }^{2}$ Moreover, in studies by Schrock and co-workers it has been found that specific polymerization catalysts give better results (like very narrow molecular weight distributions) in the presence of $N$-coordinated quinuclidine. ${ }^{3,4}$ It is supposed that coordination of this amine decreases the initiation rate in favor of the propagation rate of the polymerization

(2) Ivin, K. J. Olefin Metathesis; Academic Press: London, 1983.

(3) Schlund, R.; Schrock, R. R.; Crowe, W. E. J. Am. Chem. Soc. 1989, 111,8004 .

(4) Schrock, R. R.; Crowe, W. E.; Bazan, G. C.; DiMare, M.; O'Regan, M. B.; Schofield, M. H. Organometallics 1991, 10, 1832. 


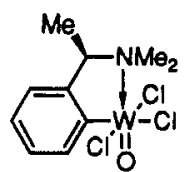

i

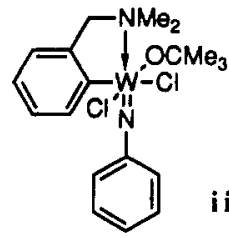

i i

Figure 1. Examples of two thermally stable aryltungsten(VI) complexes containing a chelating arylamine ligand.

reaction. In addition, it was found that coordinating solvents can play an important role in the activity of alkylidene complexes. ${ }^{5,6}$ Very recently, some studies were reported showing the large influence of the presence of trimethylphosphine on the reactivity of alkylidene complexes toward cyclic olefins. ${ }^{4,7}$ Therefore, the use of chelating arylamine ligands, which has never been applied in tungsten alkylidene chemistry, could give rise to interesting complexes and reactivities.

Recently, we published the successful synthesis of tungsten(VI) oxo and phenylimido chloride complexes containing bidentate bonded, monoanionic 2-[(dimethylamino)methyl]phenyl, and closely related arylamine ligands. ${ }^{13}$ From this study it was concluded that aryltungsten(VI) oxo and phenylimido complexes (some examples are given in Figure 1) are easily accessible and thermally very stable. These complexes are six-coordinate species in the solid state as well as in solution as a result of intramolecular W-N coordination. Obviously, it is this intramolecular W-N bonding that is responsible for the relatively good thermal stability of the complexes. It was also shown that introduction of $\pi$-donating ligands, like the tert-butoxide group, further enhances the stability of these complexes. For example, whereas complex i decomposes as a solid when exposed to air (but is thermally stable in solution up to at least $120^{\circ} \mathrm{C}$ under an inert atmosphere), complex ii can be handled in air without decomposition.

Recently, we reported our initial results of this approach in the field of tungsten alkylidene chemistry, i.e. the synthesis, characterization, and reactivity of the first tungsten(VI) alkylidene complex with intramolecular coordination. ${ }^{8}$ This paper contains full experimental and crystallographic details of this study. In addition, the introduction of extra $\pi$-electron-donating groups in the tungsten(VI) complexes is described together with the influence of these groups on the stability of alkylidene precursor complexes.

\section{Results}

Synthesis and Structure. The starting materials, $\mathrm{W}\left(\mathrm{CH}_{2} \mathrm{SiMe}_{3}\right)_{2} \mathrm{Cl}(=\mathrm{NPh})\left(\mathrm{OCMe}_{3}\right)(2), \mathrm{W}\left(\mathrm{CH}_{2} \mathrm{SiMe}_{3}\right)_{2} \mathrm{Cl}-$

(5) Klavetter, F. L.; Grubbs, R. H. J. Am. Chem. Soc. 1988, 110, 7807. (6)

(7) Wu, Z.; Wheeler, D. R.; Grubbs, R. H. J. Am. Chem. Soc. 1992, 114 146.

(8) van der Schaaf, P. A.; Smeets, W. J. J.; Spek, A. L.; van Koten, G. J. Chem. Soc., Chem. Commun. 1992, 717.

(9) Pederson, S. F.; Schrock, R. R. J. Am. Chem. Soc. 1982, 104, 7483.

(10) This dialkyltungsten(VI) alkylidene complex is described in the literature, ${ }^{9}$ where it is prepared from 1 with $\mathrm{LiCH}_{2} \mathrm{SiMe}_{3}$ at $60^{\circ} \mathrm{C}$.

(11) (a) Churchill, M. R.; Ziller, J. W.; Pederson, S. F.; Schrock, R. R. J. Chem. Soc., Chem. Commun. 1984, 485. (b) Schrock, R. R.; Pederson,

S. F.; Churchill, M. R.; Ziller, J. W. Organometallics 1984, 3, 1574.

(12) (a) Nugent, W. A.; Mayer, J. M. Metal-Ligand Multiple Bonds; John Wiley \& Sons Ltd.: New York, 1988. (b) Feldman, J.; Schrock, R. R. Prog. Inorg. Chem. 1991, 39, 1.

(13) van der Schaaf, P. A.; Boersma, J.; Kooijman, H.; Spek, A. L.; van Koten, G. Organometallics, in press.

Scheme I. Preparation of Dialkyltungsten Alkoxide and Phenoxide Complexes 2-4<smiles></smiles>

$$
\begin{aligned}
& \mathrm{CH}_{2} \mathrm{Cl}_{2} ; 0^{\circ} \mathrm{C} \\
& \hline+\mathrm{EL}_{4} \mathrm{NCl} \\
& +\mathrm{Zn}\left(\mathrm{CH}_{2} \mathrm{SiMe}_{3}\right)_{2} \\
& -\left[\mathrm{ZnCl}_{3}\right]\left[\mathrm{NEt}_{4}\right]
\end{aligned}
$$

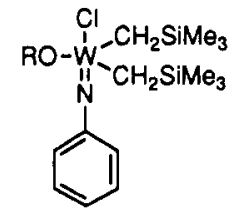

$2 \mathrm{OA}=\mathrm{OCMe}_{3}$

$3 \mathrm{OR}=\mathrm{OC}_{6} \mathrm{H}_{4} \mathrm{Me}-3,5$

$4 \mathrm{OR}=\mathrm{OC}_{6} \mathrm{H}_{4} \mathrm{Me}_{2}-2,6$

$(=\mathrm{NPh})\left(\mathrm{OC}_{6} \mathrm{H}_{3} \mathrm{Me}_{2}-3,5\right) \quad(3)$, and $\mathrm{W}\left(\mathrm{CH}_{2} \mathrm{SiMe}_{3}\right)_{2} \mathrm{Cl}-$ $(=\mathrm{NPh})\left(\mathrm{OC}_{6} \mathrm{H}_{3} \mathrm{Me}_{2}-2,6\right)(4)$, were obtained in good to excellent yields using a procedure based on the synthesis of $\mathrm{W}\left(\mathrm{CH}_{2} \mathrm{CMe}_{3}\right)_{2} \mathrm{Cl}(=\mathrm{NPh})\left(\mathrm{OCMe}_{3}\right)$ reported by Pederson and Schrock. ${ }^{9}$ This procedure employs a transmetalation reaction of a dialkylzinc reagent with a tungsten compound in the presence of tetraethylammonium chloride. The addition of $\mathrm{Et}_{4} \mathrm{NCl}$ is essential to obtain a zincfree alkyltungsten complex, since the liberated $\mathrm{ZnCl}_{2}$ is captured as insoluble $\left[\mathrm{ZnCl}_{3}\right]\left[\mathrm{NEt}_{4}\right]$; see Scheme I. In contrast to the literature procedure, $\mathrm{W}\left(\mathrm{CH}_{2} \mathrm{SiMe}_{3}\right)_{3} \mathrm{Cl}$ $(=\mathrm{NPh})(1)$ was also prepared via the procedure with $\mathrm{Et}_{4}$ $\mathrm{NCl}$ in order to obtain it absolutely free of zinc salts. The structures of 2-4 are likely to be related to that proposed for $\mathrm{W}\left(\mathrm{CH}_{2} \mathrm{CMe}_{3}\right)_{2} \mathrm{Cl}(=\mathrm{NPh})\left(\mathrm{OCM}_{3}\right) ;{ }^{9}$ i.e. the two alkyl ligands and the tert-butoxide group are bonded in the equatorial plane with both the chloride and the phenylimido group being bonded in apical positions.

Addition of a suspension of $\mathrm{Li}\left(\mathrm{C}_{6} \mathrm{H}_{4} \mathrm{CH}_{2} \mathrm{NMe}_{2}-2\right)$ in diethyl ether to a solution of 1 in diethyl ether at $-78^{\circ} \mathrm{C}$ affords, most probably, a tetraorganotungsten(VI) complex. When the reaction mixture is warmed to room temperature and stirred for $2 \mathrm{~h}$, one obtains a mixture of two alkylidene complexes, $\mathrm{W}\left(=\mathrm{CHSiMe}_{3}\right)\left(\mathrm{CH}_{2} \mathrm{Si}\right.$ $\left.\mathrm{Me}_{3}\right)_{2}(=\mathrm{NPh})^{10}$ and $\mathrm{W}\left(\mathrm{C}_{6} \mathrm{H}_{4} \mathrm{CH}_{2} \mathrm{NMe}_{2}-2\right)$ $\left(=\mathrm{CHSiMe}_{3}\right)\left(\mathrm{CH}_{2} \mathrm{SiMe}_{3}\right)(=\mathrm{NPh})(\mathbf{5})$, in a 1:4 molar ratio. These alkylidene complexes are the result of two different internal $\mathrm{H}_{\alpha}$-abstraction reactions, viz. one in which an alkyl group is liberated as $\mathrm{SiMe}_{4}$ and one in which the arylamine ligand is eliminated as $N, N$-dimethylbenzylamine; see Scheme II.

Complex 5 was obtained pure after recrystallization from pentane at $-30^{\circ} \mathrm{C}$. It can be safely handled under an inert atmosphere at $20^{\circ} \mathrm{C}$ and can be stored for months without any decomposition. However, 5 as a solid decomposes on contact with air or water and in solution (toluene) it decomposes at temperatures of $\geq 80^{\circ} \mathrm{C}$.

${ }^{1} \mathrm{H}$ NMR data for 5 in benzene show two resonances for the $\mathrm{NMe}_{2}$ methyl groups and an $\mathrm{AB}$ pattern for the methylene hydrogens of the (trimethylsilyl)methyl group; i.e. these hydrogens are diastereotopic. The diastereotopicity of the $\mathrm{NMe}_{2}$ methyl groups proves that the dimethylamine group coordinates intramolecularly to the tungsten center. When the temperature is raised to $c a .80^{\circ} \mathrm{C}$, these signals start to coalesce, indicating that at these temperatures $\mathrm{W}-\mathrm{N}$ dissociation/association processes and rotation around the $\mathrm{C}-\mathrm{N}$ bond are becoming operative on the NMR time scale. However, it is also at this temperature that 5 starts to decompose in an unclean way.

To determine the stereochemistry of 5 and to have direct proof for the intramolecular amine coordination, an X-ray structure determination was carried out. The crystal structure of 5 involves the packing of eight molecules in 
Scheme II. Proposed Mechanism for the Formation of Alkylidene Complex 5

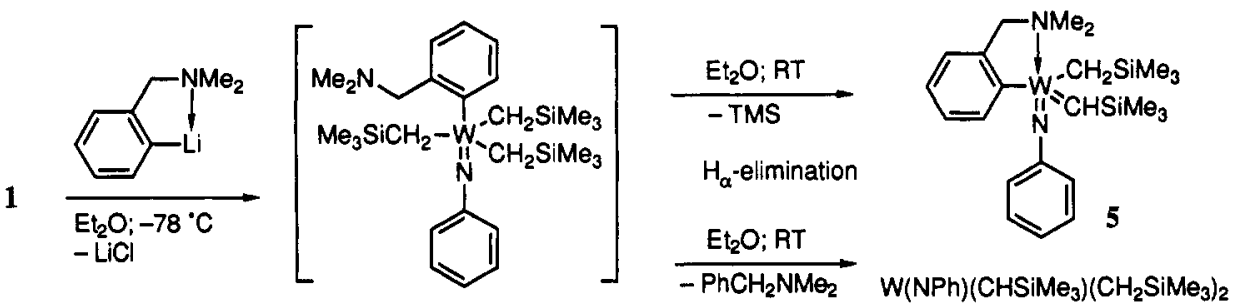

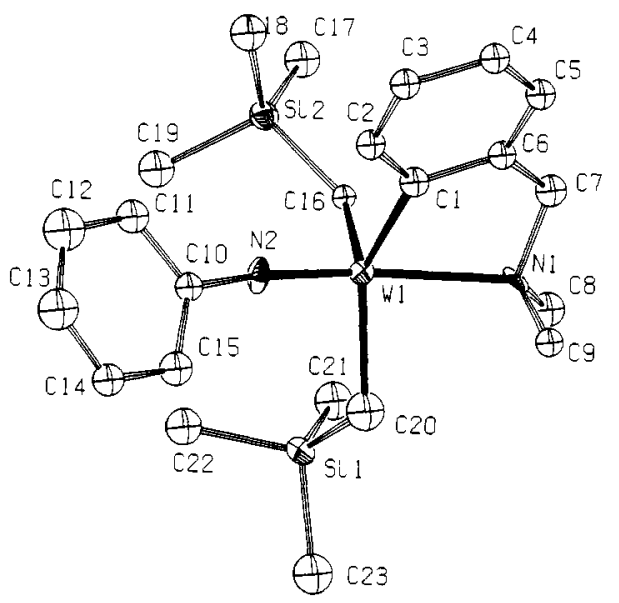

Figure 2. ORTEP drawing with adopted numbering scheme of W $\left(\mathrm{C}_{6} \mathrm{H}_{4} \mathrm{CH}_{2} \mathrm{NMe}_{2}-2\right)(=\mathrm{CHSiMe})\left(\mathrm{CH}_{2} \mathrm{SiMe}_{3}\right)(=\mathrm{NPh})(\mathbf{5})$ (50\% probability level, one molecule shown, $\mathrm{H}$-atoms omitted for clarity).

the unit cell. The asymmetric unit contains two independent, chemically equal, and crystallographically nearly identical molecules. The molecular structure of 5 is depicted in Figure 2 (one molecule shown). Atomic coordinates and selected bond lengths and angles are given in Tables I and II, respectively.

Complex 5 is the first tungsten(VI) alkylidene complex which is five-coordinate due to intramolecular $\mathrm{N}-\mathrm{W}$ coordination of a monoanionic aryl amine ligand. The molecular structure of 5 can best be described as distorted square-pyramidal (29\% and $33 \%$ distortion, with $\mathrm{C}(16)$ and $\mathrm{C}(39)$ as the respective pivots, along the Berry pseudorotation coordinate toward a trigonal bipyramid for $W(1)$ and $W(2)$, respectively). The alkylidene function is bonded at the apical position of the square pyramid with the phenylimido, ortho-chelating arylamine ligand, and remaining (trimethylsilyl)methyl group at the basal positions. The $\mathrm{W}(1)-\mathrm{N}(1)$ distance $(\mathrm{W}(2)-\mathrm{N}(3)$ in the other residue) amounts to $2.37(2) \AA$, which is comparable with, to our knowledge, the only other tertiary amine to tungsten(VI) bond length reported ${ }^{11}$ and with $\mathrm{Ta}-\mathrm{N}$ bond distances in complexes with related ligands. ${ }^{1}$ The angles around the imido nitrogen of $162.6(13)$ and $164.6(12)^{\circ}$ (for $\mathrm{W}(1)-\mathrm{N}(2)-\mathrm{C}(10)$ and $\mathrm{W}(2)-\mathrm{N}(4)-\mathrm{C}(33)$, respectively) are similar to those reported for high-valent tungsten arene-imido complexes. ${ }^{12 \mathrm{a}}$ However, it is to be noted that this angle is smaller than that found in $\mathrm{W}\left(\mathrm{C}_{6} \mathrm{H}_{4} \mathrm{CH}_{2} \mathrm{NMe}_{2}\right.$ 2) $\mathrm{Cl}_{2}(=\mathrm{NPh})\left(\mathrm{OCMe}_{3}\right)$ (ii in Figure $1 ; \mathrm{W}-\mathrm{N}-\mathrm{C}=170.4$ $\left.(7)^{\circ}\right)^{13}$ Also the bond distances and angles within the alkylidene function are in the range of those reported for other tungsten(VI) alkylidene complexes. ${ }^{12 a}$

The reaction of an equimolar amount of triphenylsilanol with 5 in pentane solution at $0^{\circ} \mathrm{C}$ affords, after several hours and after evaporation of the volatiles, $\mathrm{W}\left(\mathrm{C}_{6} \mathrm{H}_{4} \mathrm{CH}_{2}\right.$ $\left.\mathrm{NMe}_{2}-2\right)\left(=\mathrm{CHSiMe}_{3}\right)(=\mathrm{NPh})\left(\mathrm{OSiPh}_{3}\right)(6)$ quantitatively. Its ${ }^{1} \mathrm{H}$ NMR spectrum is closely related to that of 5
Table I. Fractional Coordinates and Equivalent Isotropic Thermal Parameters for $\mathrm{W}\left(\mathrm{C}_{6} \mathrm{H}_{4} \mathrm{CH}_{2} \mathrm{NMe}_{2}\right)\left(=\mathrm{CHSiMe}_{3}\right)\left(\mathrm{CH}_{2} \mathrm{SiMe}_{3}\right)(=\mathrm{NPh})(5)$ (Two Molecules)

\begin{tabular}{|c|c|c|c|c|}
\hline atom & $x$ & $y$ & $z$ & $U_{\text {eq }}, \AA^{2}$ \\
\hline $\mathrm{W}(1)$ & $0.48049(4)$ & $0.31159(5)$ & $0.46444(4)$ & $0.0150(2)$ \\
\hline $\mathrm{Si}(1)$ & $0.5149(3)$ & $0.1839(4)$ & $0.6162(3)$ & $0.0230(16)$ \\
\hline $\operatorname{Si}(2)$ & $0.3180(3)$ & $0.1689(3)$ & $0.3253(3)$ & $0.0208(17)$ \\
\hline $\mathrm{N}(1)$ & $0.6176(8)$ & $0.3419(8)$ & $0.4852(7)$ & $0.018(5)$ \\
\hline$N(2)$ & $0.3808(7)$ & $0.3270(9)$ & $0.4564(7)$ & $0.022(4)$ \\
\hline$C(1)$ & $0.4740(11)$ & $0.4088(11)$ & $0.3894(9)$ & $0.021(4)$ \\
\hline $\mathrm{C}(2)$ & $0.4081(10)$ & $0.4586(10)$ & $0.3512(9)$ & $0.021(4)$ \\
\hline$C(3)$ & $0.4041(11)$ & $0.5196(10)$ & $0.3010(9)$ & $0.022(4)$ \\
\hline$C(4)$ & $0.4757(10)$ & $0.5311(11)$ & $0.2873(9)$ & $0.021(4)$ \\
\hline$C(5)$ & $0.5434(10)$ & $0.4829(10)$ & $0.3245(9)$ & $0.022(4)$ \\
\hline$C(6)$ & $0.5432(10)$ & $0.4232(10)$ & $0.3745(9)$ & $0.019(4)$ \\
\hline$C(7)$ & $0.6155(10)$ & $0.3667(11)$ & $0.4116(9)$ & $0.024(4)$ \\
\hline $\mathrm{C}(8)$ & $0.6752(11)$ & $0.2746(11)$ & $0.5161(10)$ & $0.028(4)$ \\
\hline $\mathrm{C}(9)$ & $0.6488(10)$ & $0.4110(10)$ & $0.5402(9)$ & $0.019(4)$ \\
\hline$C(10)$ & $0.3096(11)$ & $0.3629(10)$ & $0.4583(9)$ & $0.019(4)$ \\
\hline C(11) & $0.2348(11)$ & $0.3658(11)$ & $0.3925(10)$ & $0.027(4)$ \\
\hline$C(12)$ & $0.1652(13)$ & $0.4019(13)$ & $0.3959(12)$ & $0.043(5)$ \\
\hline$C(13)$ & $0.1749(13)$ & $0.4346(13)$ & $0.4624(11)$ & $0.041(6)$ \\
\hline$C(14)$ & $0.2455(11)$ & $0.4274(11)$ & $0.5282(10)$ & $0.025(4)$ \\
\hline$C(15)$ & $0.3148(11)$ & $0.3921(11)$ & $0.5265(10)$ & $0.027(4)$ \\
\hline$C(16)$ & $0.4657(10)$ & $0.2223(9)$ & $0.4014(8)$ & $0.014(3)$ \\
\hline$C(17)$ & $0.4216(11)$ & $0.0880(11)$ & $0.2837(10)$ & $0.031(5)$ \\
\hline$C(18)$ & $0.3199(11)$ & $0.2428(11)$ & $0.2503(9)$ & $0.032(5)$ \\
\hline$C(19)$ & $0.3105(11)$ & $0.1228(11)$ & $0.3619(10)$ & $0.031(5)$ \\
\hline$C(20)$ & $0.5351(13)$ & $0.2817(11)$ & $0.5853(10)$ & $0.036(5)$ \\
\hline $\mathrm{C}(21)$ & $0.5536(12)$ & $0.0990(11)$ & $0.5791(10)$ & $0.034(5)$ \\
\hline$C(22)$ & $0.4025(10)$ & $0.1694(11)$ & $0.5843(10)$ & $0.032(5)$ \\
\hline$C(23)$ & $0.5662(11)$ & $0.1776(13)$ & $0.7232(9)$ & $0.039(5)$ \\
\hline$W(2)$ & $0.00738(4)$ & $0.68150(5)$ & $-0.00257(4)$ & $0.0168(2)$ \\
\hline $\mathrm{Si}(3)$ & $0.1307(3)$ & $0.7617(3)$ & $0.1745(3)$ & $0.0269(17)$ \\
\hline $\operatorname{Si}(4)$ & $-0.0082(3)$ & $0.8446(3)$ & $-0.1172(3)$ & $0.0236(17)$ \\
\hline$N(3)$ & $-0.1168(9)$ & $0.6539(8)$ & $0.0081(8)$ & $0.018(5)$ \\
\hline $\mathrm{N}(4)$ & $0.0975(8)$ & $0.6658(8)$ & $-0.0108(7)$ & $0.015(4)$ \\
\hline$C(24)$ & $-0.0657(11)$ & $0.6056(11)$ & $-0.0973(10)$ & $0.026(4)$ \\
\hline$C(25)$ & $-0.0385(11)$ & $0.5657(11)$ & $-0.1450(9)$ & $0.025(4)$ \\
\hline$C(26)$ & $-0.0898(10)$ & $0.5193(10)$ & $-0.2063(9)$ & $0.021(4)$ \\
\hline$C(27)$ & $-0.1733(11)$ & $0.5151(11)$ & $-0.2236(10)$ & $0.028(4)$ \\
\hline$C(28)$ & $-0.2045(11)$ & $0.5572(11)$ & $-0.1796(10)$ & $0.029(4)$ \\
\hline$C(29)$ & $-0.1518(9)$ & $0.6001(10)$ & $-0.1193(9)$ & $0.015(3)$ \\
\hline$C(30)$ & $-0.1821(11)$ & $0.6484(11)$ & $-0.0724(9)$ & $0.023(4)$ \\
\hline$C(31)$ & $-0.1433(10)$ & $0.7113(9)$ & $0.0514(8)$ & $0.018(4)$ \\
\hline$C(32)$ & $-0.1094(10)$ & $0.5710(10)$ & $0.0438(9)$ & $0.023(4)$ \\
\hline$C(33)$ & $0.1721(10)$ & $0.6327(10)$ & $-0.0081(9)$ & $0.014(4)$ \\
\hline$C(34)$ & $0.1884(11)$ & $0.6319(10)$ & $-0.0719(10)$ & $0.022(4)$ \\
\hline$C(35)$ & $0.2588(11)$ & $0.5996(12)$ & $-0.0688(11)$ & $0.032(5)$ \\
\hline$C(36)$ & $0.3168(11)$ & $0.5665(11)$ & $-0.0031(9)$ & $0.024(4)$ \\
\hline$C(37)$ & $0.3053(10)$ & $0.5686(11)$ & $0.0625(9)$ & $0.022(4)$ \\
\hline$C(38)$ & $0.2322(9)$ & $0.6010(10)$ & $0.0594(9)$ & $0.015(3)$ \\
\hline$C(39)$ & $-0.0272(10)$ & $0.7825(9)$ & $-0.0449(9)$ & $0.017(4)$ \\
\hline$C(40)$ & $-0.0507(12)$ & $0.9477(12)$ & $-0.1248(11)$ & $0.040(5)$ \\
\hline$C(41)$ & $-0.0576(12)$ & $0.7938(12)$ & $-0.2086(10)$ & $0.040(5)$ \\
\hline$C(42)$ & $0.1042(10)$ & $0.8546(11)$ & $-0.0898(10)$ & $0.029(4)$ \\
\hline$C(43)$ & $0.0613(10)$ & $0.6786(11)$ & $0.1193(8)$ & $0.023(4)$ \\
\hline$C(44)$ & $0.1856(11)$ & $0.8126(13)$ & $0.1235(10)$ & $0.039(5)$ \\
\hline$C(45)$ & $0.2116(13)$ & $0.7196(13)$ & $0.2634(11)$ & $0.051(6)$ \\
\hline$C(46)$ & $0.0698(14)$ & $0.8373(15)$ & $0.1995(12)$ & $0.066(7)$ \\
\hline
\end{tabular}

a $U_{\text {eq }}$ is one-third of the trace of the orthogonalized $\mathbf{U}$.

(see Tables III and IV), although the (trimethylsilyl)methyl group is now replaced by a triphenylsiloxy group. Both methyls of the dimethylamino group and the hydrogen 
Table II. Selected Geometrical Data for $\mathrm{W}\left(\mathrm{C}_{6} \mathrm{H}_{4} \mathrm{CH}_{2} \mathrm{NMe}_{2}-2\right)\left(=\mathrm{CHSiMe}_{3}\right)\left(\mathrm{CH}_{2} \mathrm{SiMe}_{3}\right)(=\mathrm{NPh})(5)$

molecule 1 molecule 2

\begin{tabular}{|c|c|c|c|}
\hline \multicolumn{2}{|c|}{ molectule 1} & \multicolumn{2}{|l|}{ mojecule 2} \\
\hline \multicolumn{4}{|c|}{ Bond Lengths $(\AA)$} \\
\hline$W(1)-C(1)$ & $2.149(18)$ & $W(2)-C(24)$ & $2.153(18)$ \\
\hline$W(1)-C(16)$ & $1.872(15)$ & $W(2)-C(39)$ & $1.857(15)$ \\
\hline$W(1)-C(20)$ & $2.182(18)$ & $W(2)-C(43)$ & $2.143(14)$ \\
\hline $\mathbf{W}(1)-\mathbf{N}(1)$ & $2.370(15)$ & $W(2)-N(3)$ & $2.371(17)$ \\
\hline $\mathrm{W}(1)-\mathrm{N}(2)$ & $1.747(14)$ & $W(2)-N(4)$ & $1.713(15)$ \\
\hline$N(2)-C(10)$ & $1.43(2)$ & $N(4)-C(33)$ & $1.43(2)$ \\
\hline $\mathrm{Si}(1)-\mathrm{C}(20)$ & $1.82(2)$ & $\operatorname{Si}(3)-C(43)$ & $1.862(18)$ \\
\hline $\mathrm{Si}(2)-C(16)$ & $1.832(17)$ & $\operatorname{Si}(4)-C(39)$ & $1.890(17)$ \\
\hline \multicolumn{4}{|c|}{ Bond Angles (deg) } \\
\hline$N(1)-W(1)-C(1)$ & $72.8(6)$ & $N(3)-W(2)-C(24)$ & $73.3(7)$ \\
\hline$N(1)-W(1)-C(16)$ & $97.2(7)$ & $N(3)-W(2)-C(39)$ & $93.8(7)$ \\
\hline $\mathbf{N}(1)-\mathbf{W}(1)-\mathbf{C}(20)$ & $85.0(7)$ & $N(3)-W(2)-C(43)$ & $83.8(6)$ \\
\hline $\mathbf{N}(1)-W(1)-\mathbf{N}(2)$ & $158.8(6)$ & $N(3)-W(2)-N(4)$ & $160.1(6)$ \\
\hline$C(1)-W(1)-C(16)$ & $101.6(6)$ & $C(24)-W(2)-C(39)$ & $100.7(7)$ \\
\hline$C(1)-W(1)-C(20)$ & $140.6(7)$ & $C(24)-W(2)-C(43)$ & $138.9(7)$ \\
\hline$C(16)-W(1)-C(20)$ & $113.4(7)$ & $C(39)-W(2)-C(43)$ & $114.7(7)$ \\
\hline$W(1)-C(20)-S i(1)$ & $119.9(10)$ & $W(2)-C(43)-S i(3)$ & $119.6(9)$ \\
\hline$W(1)-C(16)-S i(2)$ & $138.5(11)$ & $W(2)-C(39)-S i(4)$ & $133.8(10)$ \\
\hline $\mathbf{W}(1)-\mathbf{N}(2)-C(10)$ & $162.6(13)$ & $\mathrm{W}(2)-\mathrm{N}(4)-\mathrm{C}(33)$ & $164.6(12)$ \\
\hline
\end{tabular}

atoms of the $\mathrm{CH}_{2} \mathrm{~N}$ unit remain diastereotopic, indicating that in 6 the arylamine ligand is also bidentate bonded. Therefore, the proposed structure for 6 is like that of 5 , $v i z$. a five-coordinate tungsten(VI) alkylidene complex with an intramolecularly coordinating dimethylamino group; see Scheme III. The chemical shift of $\mathrm{H}_{\alpha}$ in $\mathbf{6}$ is shifted to a lower field, $10.09 \mathrm{ppm}\left({ }^{2} J_{\mathrm{WH}}=11.1 \mathrm{~Hz}\right)$ with respect to the corresponding signal for 5 at $8.25 \mathrm{ppm}\left({ }^{2} J_{\mathrm{WH}}=10.3\right.$ $\mathrm{Hz}$ ).

When this alcoholysis reaction of 5 is carried out with tert-butanol instead of triphenylsilanol, $\mathrm{W}\left(\mathrm{C}_{6} \mathrm{H}_{4} \mathrm{CH}_{2}\right.$. $\left.\mathrm{NMe}_{2}-2\right)\left(\mathrm{CH}_{2} \mathrm{SiMe}_{3}\right)_{2}(=\mathrm{NPh})\left(\mathrm{OCMe}_{3}\right)(7)$ is obtained. However, complex 7 obtained via this reaction was not pure, even when it is performed at low temperature $(-40$ $\left.{ }^{\circ} \mathrm{C}\right)$. Attempts to purify 7 via recrystallization or washing procedures were unsuccessful due to its extremely good solubility, even in pentane. A successful synthesis of pure 7 is the reaction of $\mathrm{Li}\left(\mathrm{C}_{6} \mathrm{H}_{4} \mathrm{CH}_{2} \mathrm{NMe}_{2}-2\right)$ with 2 in diethyl ether at $-78^{\circ} \mathrm{C}$. After workup crystalline 7 could then be obtained from a minimum of hexane at $-30^{\circ} \mathrm{C}$. The ${ }^{1} \mathrm{H}$ NMR spectrum at room temperature of 7 is rather complex but clearly shows three resonance patterns (ratio approximately 5:8:4), which we ascribe to three different isomers $(7 \mathrm{a}, 7 \mathbf{b}$, and $7 \mathrm{c}$, respectively) and in which, besides the arylamine ligand and the phenylimido group, two (trimethylsilyl)methyl ligands and one tert-butoxide group are present.

Interestingly, when an NMR sample is prepared from recrystallized 7 at $-78^{\circ} \mathrm{C}$ in toluene- $d_{8}$ and its spectrum is recorded at $-70^{\circ} \mathrm{C}$, just one of the three resonance patterns is observed and this is due to the presence of only isomer 7a in solution (see Tables III and IV). The resonance pattern of this isomer shows that the $\mathrm{NMe}_{2}$ methyl groups and $\mathrm{CH}_{2} \mathrm{~N}$ hydrogen atoms are diastereotopic, pointing to bidentate $\mathrm{C}, \mathrm{N}$-bonding of the arylamine ligand in $7 \mathbf{a}$; see Figure 3.

Recently, we determined the solid-state structure of complex W $\left(\mathrm{C}_{6} \mathrm{H}_{4} \mathrm{CH}_{2} \mathrm{NMe}_{2}-2\right) \mathrm{Cl}_{2}(=\mathrm{NPh})\left(\mathrm{OCMe}_{3}\right)$ (see ii in Figure 1), in which two chloride ligands are present instead of the two $\mathrm{CH}_{2} \mathrm{SiMe}_{3}$ groups in 7a. ${ }^{13}$ This halide complex has an octahedral geometry in which the two chlorides, the tert-butoxide group, and $\mathrm{C}_{i p s o}$ are bonded equatorially. Accordingly, for $7 \mathrm{a}$ we propose a similar sixcoordinate structure in which $\mathrm{C}_{i p s o}$, the tert-butoxide group, and two alkyl ligands are bonded in the equatorial plane, while the tertiary amine ligand and the phenylimido group are in trans positions and occupy the apical positions. Because of the diastereotopicity of both the $\mathrm{CH}_{2} \mathrm{~N}$ and $\mathrm{CH}_{2} \mathrm{Si}$ hydrogen atoms, that indicates that a molecular symmetry plane containing these carbon atoms is absent, the two $\mathrm{CH}_{2} \mathrm{SiMe}_{3}$ groups have to be bonded cis with respect to each other. When the low temperature NMR sample of 7 , containing exclusively isomer $7 \mathrm{a}$, is warmed, the resonance patterns for the other two isomers, $7 \mathbf{b}$ and $7 \mathrm{c}$, start to appear at $-30^{\circ} \mathrm{C}$. When room temperature is reached, the spectrum is similar to the one obtained when a sample of 7 is dissolved and measured without further precautions. The resonance patterns of $7 \mathbf{b}$ and $7 \mathrm{c}$ both contain homotopic $\mathrm{NMe}_{2}$ methyl groups and $\mathrm{CH}_{2} \mathrm{~N}$ hydrogens at room temperature. For one of these isomers, $7 \mathrm{c}$, the $o-\mathrm{H}$ of the aryl group $(8.20 \mathrm{ppm})$ is shifted to lower field with respect to the free ligand, as was found for $7 \mathrm{a}$ $(8.48 \mathrm{ppm})$. This strongly suggests that in $7 \mathrm{c}$ the arylamine ligand is bidentate bonded in the same way as in 7a; i.e. the $\mathrm{o}-\mathrm{H}$ of the arylamine ligand points toward the nitrogen atom of the phenylimido group. (Information on the substituent effect observed for $0-\mathrm{H}$ in a series of related arylamine-containing tungsten(VI) phenylimido chloride complexes is to be found in ref 13.) The resonance pattern for isomer $7 \mathbf{b}$, measured at room temperature shows singlet resonances for the $\mathrm{NMe}_{2}$ methyl groups and $\mathrm{CH}_{2} \mathrm{~N}$ hydrogen atoms. This pattern starts to decoalesce at -35 ${ }^{\circ} \mathrm{C}$ and forms at $-60^{\circ} \mathrm{C}$ an $\mathrm{AB}$ pattern for the $\mathrm{CH}_{2} \mathrm{~N}$ hydrogens and two distinct singlets for the $\mathrm{NMe}_{2}$ methyl groups, indicating that $\mathrm{W}-\mathrm{N}$ dissociation/association processes have then become slow on the NMR time scale. Furthermore, the $o-\mathrm{H}$ of the aryl group in this isomer is not shifted significantly to lower field (7.51 ppm), as is the case for $7 \mathrm{a}$ and $7 \mathrm{c}$. Therefore, $7 \mathrm{~b}$ is proposed to be fivecoordinate at room temperature (see Figure 3). The diastereotopicity observed for the $\mathrm{CH}_{2} \mathrm{~N}$ hydrogens and the $\mathrm{NMe}_{2}$ methyl groups at low temperatures suggests that $\mathbf{7 b}$ is then a six-coordinated species in which the arylamine ligand is bidentate bonded and occupies, together with the phenylimido group, one face of the octahedron.

In conclusion, 7 exists in solution as a mixture of three isomers of which two (7a and 7c) can be assigned unambiguously. From this solution 7 crystallizes out as isomer 7a which upon dissolution at $-70^{\circ} \mathrm{C}$ retains its stereochemistry. When the equilibrium mixture of 7 has been established at room temperature, cooling to $-70^{\circ} \mathrm{C}$ does not change its composition significantly and the molar ratio of $7 \mathrm{a}: 7 \mathrm{~b}: 7 \mathrm{c}$ of $5: 8: 4$ found at room temperature is concentration independent. It is only $7 b$ which exhibits temperature dependent fluxional behaviour: i.e. $7 \mathbf{a}$ and $7 \mathrm{c}$ have rigid structures on the NMR time scale. Finally, it should be noted that 7 is monomeric in solution (cryoscopy in benzene, see Experimental Section). Attempts to study the equilibrium mixture of 7 (most probably involving a sequence of Berry pseudorotations) in solution at higher temperatures were hampered by decomposition above $c a .70^{\circ} \mathrm{C}$.

Complex 7, like the proposed tetraorganotungsten precursor for 5 depicted in Scheme II, can decompose via different intramolecular $\mathrm{H}_{\alpha}$-abstraction reaction pathways. In the ${ }^{1} \mathrm{H}$ NMR spectrum of 7 at elevated temperatures the formation of tetramethylsilane and, to a lesser extent, $N, N$-dimethylbenzylamine occurs. Simultaneously, the 
Table III. Selected ${ }^{1}$ H NMR Data ${ }^{\star}$ for the Arylamine-Containing Organotungsten(VI) Complexes ${ }^{b}$

\begin{tabular}{|c|c|c|c|c|c|}
\hline complex & $\mathbf{H}_{\alpha}$ & $0 . \mathrm{H} \mathrm{Ar}$ & $p-\mathrm{H} \mathrm{NPh}$ & $\mathrm{CH}_{2} \mathrm{~N}$ & $\mathrm{NMe}_{2}$ \\
\hline $\begin{array}{l}\text { W(Ar) }\left(=\mathrm{CHSiMe}_{3}\right)\left(\mathrm{CH}_{2} \mathrm{SiMe}_{3}\right)(=\mathrm{NPh})(5) \\
\text { W(Ar) }\left(=\mathrm{CHSiMe}_{3}\right)(=\mathrm{NPh})\left(\mathrm{OSiPh}_{3}\right)(6) \\
\text { W(Ar) }\left(\mathrm{CH}_{2} \mathrm{SiMe}_{3}\right)(=\mathrm{NPh})\left(\mathrm{OCMe}_{3}\right)^{e}(7 \mathrm{a}) \\
\text { W(Ar) }\left(\mathrm{CH}_{2} \mathrm{SiMe}_{3}\right)_{2}(=\mathrm{NPh})\left(\mathrm{OC}_{6} \mathrm{H}_{3} \mathrm{Me}_{2}-3,5\right)(9)\end{array}$ & $\begin{array}{l}8.25^{c} \\
10.09^{d} \\
(9.82)^{f} \\
(10.13)^{f}\end{array}$ & $\begin{array}{l}8.41 \\
8.62 \\
8.488 \\
7.81\end{array}$ & $\begin{array}{l}6.94 \\
6.82 \\
6.71 \\
6.82\end{array}$ & $\begin{array}{l}3.98,3.32 \\
3.78,3.19 \\
4.10,2.85^{h} \\
3.52\end{array}$ & $\begin{array}{l}2.45,1.59 \\
2.46,1.85 \\
2.12,2.10 \\
2.13\end{array}$ \\
\hline
\end{tabular}

${ }^{a}$ Chemical shifts are in $\delta$ relative to $\mathrm{SiMe}_{4},{ }^{b} \mathrm{Ar}=2-\left[\right.$ (dimethylamino)methyl]phenyl. ${ }^{c}{ }^{2} J_{\mathrm{WH}}=10.3 \mathrm{~Hz}$. ${ }^{d}{ }^{2} J_{\mathrm{WH}}=11.1 \mathrm{~Hz}$. ${ }^{e} \mathrm{Resonances}$ of the isomer which is obtained when the sample is prepared and measured at low temperatures. ${ }^{f}$ Signal observed during decomposition ( ${ }^{2} J_{\mathrm{WH}}$ not observed). $87 \mathrm{~b}, 7.51 ; 7 \mathrm{c}, 8.20{ }^{h} \mathrm{7b}, 3.30 ; 7 \mathrm{c}, 3.58$.

Table IV. Selected ${ }^{13} \mathrm{C}$ NMR Data* for the dmba-Containing Organotungsten(VI) Complexes ${ }^{b}$

\begin{tabular}{|c|c|c|c|c|}
\hline complex & $C_{\text {ipso }}$ aryl $^{c}$ & $\mathrm{C}_{\text {ipso }} \mathrm{NPh}$ & $\mathrm{CH}_{2} \mathrm{~N}$ & $\mathrm{NMe}_{2}$ \\
\hline $\begin{array}{l}\mathrm{W}(\mathrm{Ar})\left(=\mathrm{CHSiMe}_{3}\right)\left(\mathrm{CH}_{2} \mathrm{SiMe}_{3}\right)(=\mathrm{NPh})(5) \\
\mathrm{W}(\mathrm{Ar})\left(=\mathrm{CHSiMe}_{3}\right)(=\mathrm{NPh})\left(\mathrm{OSiPh}_{3}\right)(6) \\
\mathrm{W}(\mathrm{Ar})\left(\mathrm{CH}_{2} \mathrm{SiMe}_{3}\right)_{2}(=\mathrm{NPh})\left(\mathrm{OCMe}_{3}\right)^{d}(7) \\
\mathrm{W}(\mathrm{Ar})\left(\mathrm{CH}_{2} \mathrm{SiMe}_{3}\right)_{2}(=\mathrm{NPh})\left(\mathrm{OC}_{6} \mathrm{H}_{3} \mathrm{Me}_{2}-3,5\right)(9)\end{array}$ & $\begin{array}{l}190.0(109.3) \\
182.0(128.5) \\
190.0^{e} \\
188.9(105.5)\end{array}$ & $\begin{array}{l}156.6 \\
155.8 \\
156.6 \\
155.0\end{array}$ & $\begin{array}{l}75.1 \\
71.2 \\
75.1 \\
70.4\end{array}$ & $\begin{array}{l}49.3,45.8 \\
48.4,45.7 \\
49.3,45.8 \\
47.6\end{array}$ \\
\hline
\end{tabular}

${ }^{a}$ Chemical shifts are in $\delta$ relative to $\mathrm{SiMe}_{4} \cdot{ }^{b} \mathrm{Ar}=2$-[(dimethylamino)methyl]phenyl. ${ }^{c}{ }^{1} J_{\mathrm{Wc}}$ in parentheses, in $\mathrm{Hz} .{ }^{d} \mathrm{Resonances}$ of the isomer which is obtained when the sample is prepared and measured at low temperatures. $\left[1 J_{\mathrm{Wc}}\right.$ not observed.

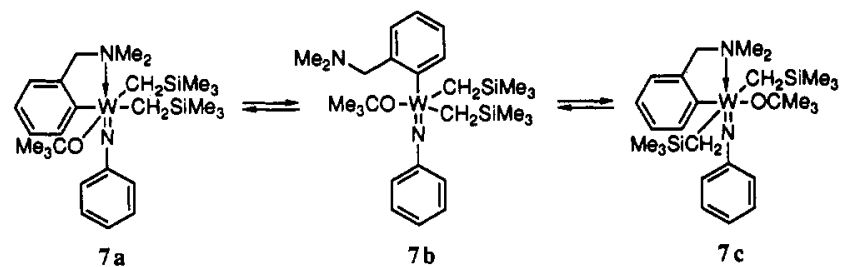

Figure 3. Proposed isomeric structures for complex 7.

Scheme III. Formation of Complex 6

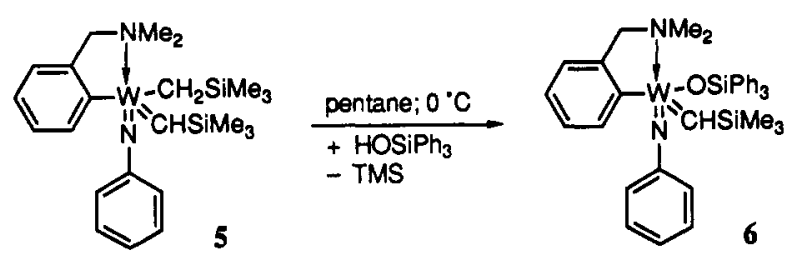

appearance of a signal at $9.82 \mathrm{ppm}$ corresponding to an alkylidene hydrogen is observed. A possible composition for the species formed is $\mathrm{W}\left(\mathrm{C}_{6} \mathrm{H}_{4} \mathrm{CH}_{2} \mathrm{NMe}_{2}-2\right)(=\mathrm{CHSi}$ $\left.\mathrm{Me}_{3}\right)(=\mathrm{NPh})\left(\mathrm{OCMe}_{3}\right)(8)$, which is an analog of 5 in which the (trimethylsilyl)methyl group is replaced by a tertbutoxide group. The resonance patterns of 7 disappear upon prolonged heating, while the signal at $9.82 \mathrm{ppm}$ of the $\mathrm{H}_{\alpha}$ atom from the newly formed alkylidene complex 8 also gradually vanishes. The final NMR spectrum (after $8 \mathrm{~h}$ ) contains signals from products that have as yet not been identified.

When $\mathrm{Li}\left(\mathrm{C}_{6} \mathrm{H}_{4} \mathrm{CH}_{2} \mathrm{NMe}_{2}-2\right)$ is reacted with 3 , which contains the weakly $\pi$-donating 3,5-dimethylphenoxide group instead of the tert-butoxide group in $2, \mathrm{~W}\left(\mathrm{C}_{6} \mathrm{H}_{4}\right.$ $\left.\mathrm{CH}_{2} \mathrm{NMe}_{2}-2\right)\left(\mathrm{CH}_{2} \mathrm{SiMe}_{3}\right)_{2}(=\mathrm{NPh})\left(\mathrm{OC}_{6} \mathrm{H}_{4} \mathrm{Me}_{2}-3,5\right)(9)$ is obtained. According to its ${ }^{1} \mathrm{H}$ NMR spectrum at room temperature 9 is a five-coordinate dialkyltungsten complex with a noncoordinating dimethylamino group. One of the $\mathrm{CH}_{2} \mathrm{Si}$ groups appears as a broad, poorly resolved $\mathrm{AB}$ pattern, whereas the second $\mathrm{CH}_{2} \mathrm{Si}$ group appears as a singlet. However, a ${ }^{1} \mathrm{H}$ NMR spectrum recorded at -30 ${ }^{\circ} \mathrm{C}$, reveals diastereotopicity of the $\mathrm{CH}_{2} \mathrm{Si}$ and $\mathrm{CH}_{2} \mathrm{~N}$ hydrogen atoms, as well as of the $\mathrm{NMe}_{2}$ methyl groups, indicating that at these temperatures $\mathrm{W}-\mathrm{N}$ coordination occurs. Above $60^{\circ} \mathrm{C}$, regrettably, an unclean decomposition reaction takes place, and just a trace of a new tungsten(VI) alkylidene complex $\left(\mathrm{H}_{\alpha}\right.$ at $\left.10.13 \mathrm{ppm}\right)$ was observed.

So far the use of 4 as starting material for the synthesis of an alkylidene complex that contains a 2,6-dimethylphenoxide ligand has resulted in the formation of product mixtures. Even when both reaction and workup procedure were carried out at $0^{\circ} \mathrm{C}$, the expected analog of 9 could not be isolated.

Reactivity of the New Alkylidene Complexes. The reactivity study of the new tungsten(VI) alkylidene complexes has been restricted to complexes 5 and 6 , since only these could be obtained analytically pure.

It was found that 5 and 6 are inert toward linear, internal and terminal olefins (cis-2-pentene, neohexene, and ethene (1 atm)). Acrylonitrile reacts with 5, most probably through anchimeric assistance of the cyano group, and this leads to quantitative formation of vinyltrimethylsilane, which is the product of a single step metathesis reaction. Attempts to isolate the newly formed cyanocarbene complex, the tungsten-containing product of this reaction, were unsuccessful.

Aldehydes (pivaldehyde and benzaldehyde) and acetone react in a fast Wittig-type reaction with solutions of 5 or 6 in benzene and a new olefin is obtained as a cis/trans mixture with the trans product as the major component; see Scheme IV. Unfortunately, the tungsten-containing product of this reaction (presumably a tungsten phenylimido oxo complex) could not be isolated.

The reaction of 5 and 6 with strained cyclic olefins is very fast and affords polymeric products. For example, the reaction of 5 with 250 equiv of norbornadiene or dicyclopentadiene (cyclic olefins with two olefin bonds) in benzene proceeds quantitatively (complete within seconds for norbornadiene and several minutes for dicyclopentadiene) to give insoluble polymers. These polymers are likely to be strongly cross-linked as a consequence of the two olefin bonds in the starting monomer; see Scheme $V$. The reaction of 5 and 6 with 200 equiv of norbornene gives, after quenching the reaction mixture with a drop of benzaldehyde and evaporation of the volatiles, quantitative formation of a colorless elastic plastic film. This film can be dissolved in benzene, and this enables the study of the cis:trans ratio of the vinylene bonds with ${ }^{1} \mathrm{H}$ NMR spectroscopy. ${ }^{14}$ This study showed that these fivecoordinate alkylidene complexes produce polymers with almost exclusively $(>90 \%)$ the cis-vinylene bond configuration.

(14) Schrock, R. R.; Feldman, J.; Cannizzo, L. F.; Grubbs, R. H. Macromolecules 1987, 20, 1172. 

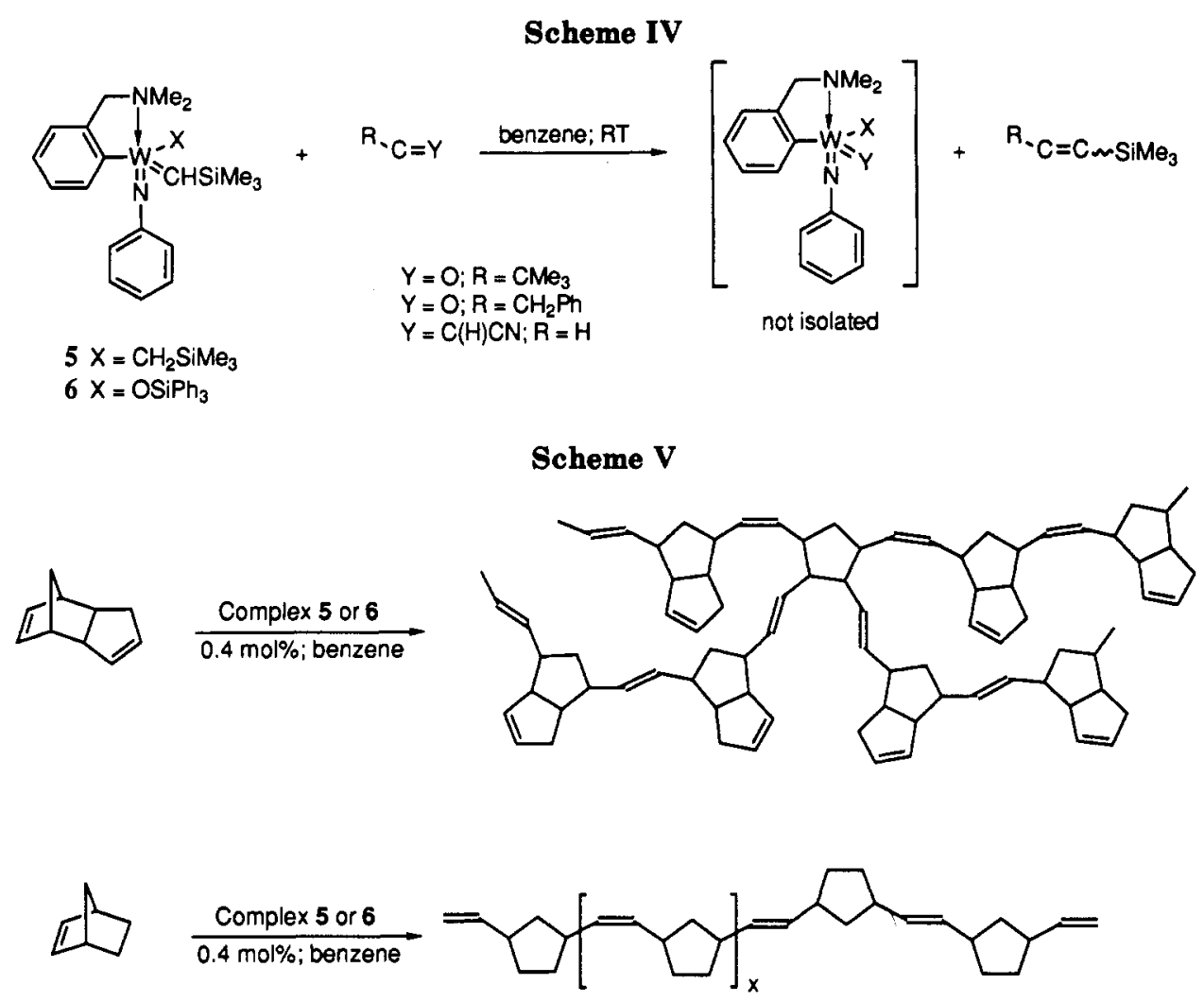

\section{Discussion}

The two new tungsten(VI) alkylidene complexes $\mathrm{W}\left(\mathrm{C}_{6} \mathrm{H}_{4} \mathrm{CH}_{2} \mathrm{NMe}_{2}-2\right)\left(=\mathrm{CHSiMe}_{3}\right)(=\mathrm{NPh})(\mathrm{R})\left(\mathrm{R}=\mathrm{CH}_{2}-\right.$ $\mathrm{SiMe}_{3}(5) ; \mathrm{R}=\mathrm{OSiPh}_{3}(6)$ are easily accessible as compared with the syntheses of most of the known, well-characterized, tungsten alkylidene complexes that are active catalysts in olefin metathesis reactions. The reason that the use of chelating arylamine ligands allows easy synthesis of tungsten(VI) alkylidene complexes is probably related to the stabilization generated by intramolecular $\mathrm{W}-\mathrm{N}$ coordination. . $^{2 \mathrm{~b}}$

NMR experiments show that in solution 5 and 6 are five-coordinate species at room temperature. At higher temperatures 5 and 6 have only limited stability; i.e. decomposition starts at $c a .70^{\circ} \mathrm{C}$. At this temperature the signals for the diastereotopic $\mathrm{NMe}_{2}$ methyl groups and the $\mathrm{CH}_{2} \mathrm{~N}$ hydrogen atoms start to coalesce, indicating that $\mathrm{W}-\mathrm{N}$ dissociation/association processes take place. In the dissociated form the tungsten center in $\mathbf{5}$ and $\mathbf{6}$ is four-coordinate and as a consequence it is more electron deficient. In the absence of intramolecular amine coordination the arylamine ligand is monodentate $\mathrm{C}$-bonded which allows rotation of the aryl ring around the $\mathrm{W}-\mathrm{C}_{\text {ipso }}$ axis. In this bonding mode the $\mathrm{O}-\mathrm{H}$ atom of the aryl ring or benzylic hydrogens of the $0-\mathrm{CH}_{2} \mathrm{NMe}_{2}$ substituent can come close to other ligands present in the coordination sphere of the metal center, and this may result in a $\beta$-hydrogen elimination reaction. However, no proof is found for this decomposition pathway because after complete decomposition of 5 and $\mathbf{6}$, no defined products could be isolated and characterized. It is interesting to note that this $\mathrm{W}-\mathrm{N}$ coordination in aryltungsten phenylimido chloride complexes ${ }^{13}$ (see examples in Figure 1) is much stronger than in the corresponding aryltungsten phenylimido alkyl alkoxide and phenoxide complexes. In the aryltungsten(VI) phenylimido chloride complexes the $\mathrm{W}-\mathrm{N}$ dissociation/association processes were not observed.
This indicates the bond strength of the $\mathrm{W}-\mathrm{N}$ coordination is strongly dependent on the electron deficiency of the metal center: in the series $\mathrm{WCl}, \mathrm{WCH}_{2} \mathrm{R}$, WOR the electron deficiency decreases and this is reflected in weaker $\mathrm{W}-\mathrm{N}$ bonding.

The reactions of triphenylsilanol and tert-butyl alcohol with 5 (giving complexes 6 and 7, respectively) nicely demonstrate the individual steps in the hydrolysis of an alkylidene complex, which is followed by an $\mathrm{H}_{\alpha}$-abstraction reaction (affording a new alkylidene complex). Osborn et al. recently prepared molybdenum alkylidene complexes containing the weakly $\pi$-donating triphenylsiloxy group via a ligand substitution reaction of a tungsten alkylidene dialkoxide complex with $\mathrm{Ph}_{3} \mathrm{SiOH} .{ }^{15}$ The product of this reaction is an alkylidene complex in which one of the alkoxide ligands is replaced by the siloxy group. The reaction between 5 and triphenylsilanol, when performed at low temperature, is very clean and just one product (6) is obtained. When we tried to prepare an alkylidene complex analoguous to 6 , in which a tert-butoxide group is present (via alcoholysis of 5 with tert-butyl alcohol), the dialkyl complex 7 was obtained. This complex can be considered as an intermediate in the ligand substitution reaction described above. Similar reactions were found by Osborn et al. when a dialkyltungsten alkylidene complex, $\mathrm{W}\left(=\mathrm{CHCMe}_{3}\right)\left(\mathrm{CH}_{2} \mathrm{CMe}_{3}\right)_{2}\left(=\mathrm{NCMe}_{3}\right)$, was reacted with pentafluorophenol and triphenylsilanol. The phenol reacts in a 1,2-addition reaction, whereas the silanol leads to a ligand exchange reaction. Thus, the first step in such a reaction appeared to be a 1,2-addition reaction on the alkylidene function, and this, in the case of the siloxy group, is immediately followed by an $\mathrm{H}_{\alpha}$-abstraction reaction. This proposed reaction sequence is depicted in Scheme VI.

In both complexes 6 and 7 an O-bonded ligand is present

(15) Ehrenfeld, D.; Kress, J.; Moore, B. M.; Osborn, J. A.; Schoettel, G. J. Chem. Soc., Chem. Commun. 1987, 129 . 


\section{Scheme VI}
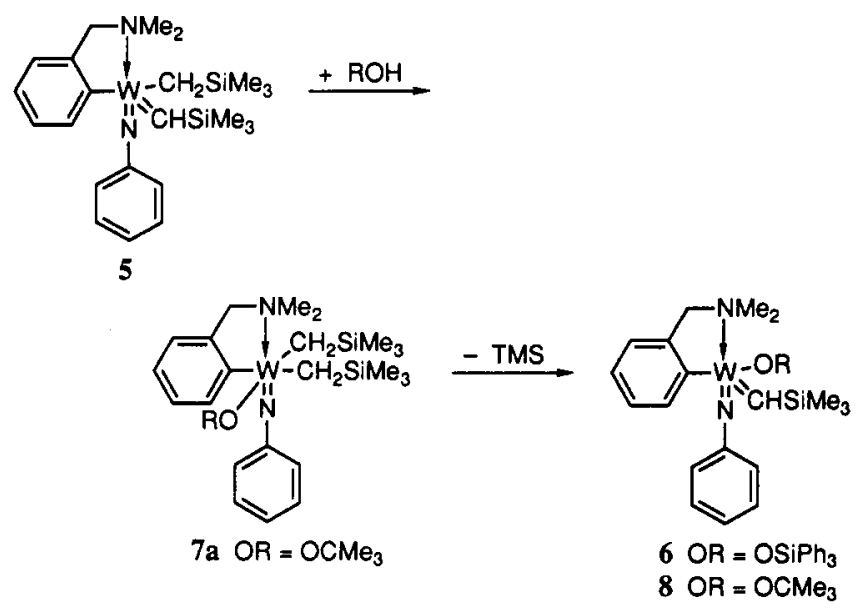

(of which the tert-butoxide is a stronger $\pi$-donating group than the triphenylsiloxy group), nicely demonstrating the driving force for a tungsten complex to form an alkylidene function from two alkyl groups via an internal $\mathrm{H}_{\alpha^{-}}$ abstraction reaction. As is known from the literature, the formation of an alkylidene function offers an electronic advantage for the electron deficient $\mathrm{d}^{0}$-tungsten center. . $^{12 \mathrm{a}}$ Therefore, if a strong $\pi$-donating ligand, like the tertbutoxide group, is bonded to the tungsten center, the alkylidene precursor is more stable toward an internal abstraction reaction than when a weaker donor, such as the triphenylsiloxy group, is present. Therefore, the alkylidene precursor complex 7 (with a tert-butoxide group) is isolable, whereas alkylidene complex 6 (with a triphenylsiloxy group) is already formed at low temperatures.

The reactivity of alkylidene complexes toward substrates as olefins and aldehydes strongly depends not only on the electronic properties but also on the structural aspects of the alkylidene complex. We find that the reactivity of the alkylidene complexes 5 and 6 toward a variety of substrates is nearly identical. In these complexes the steric constraints caused by a (trimethylsilyl)methyl group and triphenylsiloxy group are expected to be similar and the electronic properties of the metal centers are assumed to be very similar as well. An efficient tool for comparing electronic properties of related complexes is the chemical shift of $C_{i p s o}$, and its ${ }^{1} J_{\mathrm{Wc}}$, of the aryl ligand. ${ }^{13}$ According to these data 6 is just slightly less electron deficient than 5. Thus, both complexes are not only structurally very similar but also electronically. This is nicely reflected in the reactivities of both complexes: no significant difference was observed in relative reaction rates toward olefins and aldehydes. Even the favored formation of the trans-olefins over cis isomers during the reaction with aldehydes was found for both complexes. Moreover, both 5 and 6 led to the quantitative formation of polymers with almost exclusively cis-vinylene bonds as the product of the polymerization reaction of norbornene.

\section{Conclusions}

The present study demonstrates that tungsten phenylimido alkylidene complexes are very easily accessible in a three-step synthesis (from $\mathrm{W}(0) \mathrm{Cl}_{4}$ ) when a potentially chelating ligand is used. The ligand, a monoanionic aryl system containing an $0-\mathrm{CH}_{2} \mathrm{NMe}_{2}$ substituent, not only stabilizes aryltungsten complexes but, as a result of the amine substituent which is always held in the proximity of the metal center, also facilitates intramolecular $\mathrm{H}_{\alpha^{-}}$ abstraction and the subsequent formation of an alkylidene function. The resulting alkylidene complexes are fivecoordinate as a result of intramolecular $\mathrm{W}-\mathrm{N}$ coordination that is, however, much weaker than in related aryltungsten(VI) phenylimido chloride complexes. The $\mathrm{W}-\mathrm{N}$ bond remains intact on the NMR time scale at room temperature in benzene solution, but at ca. $70^{\circ} \mathrm{C} \mathrm{W}-\mathrm{N}$ dissociation processes are operative and the complexes start to decompose. This behavior indicates the importance of $\mathrm{W}-\mathrm{N}$ coordination with respect to the stability of such alkylidene complexes. These new alkylidene complexes react with aldehydes in a Wittig-type reaction affording predominantly trans-olefins. The reactivity of these new alkylidene complexes in olefin metathesis reactions is restricted to strained cyclic olefins, which are polymerized in a ROMP reaction; for example 5 reacts with norbornene to afford polycyclopentenamers with $>90 \%$ cis-vinylene bonds.

\section{Experimental Section}

General Considerations. All reactions were carried out in an atmosphere of dry, deoxygenated dinitrogen, using standard Schlenk techniques. Solvents were distilled from sodium benzophenone ketyl under nitrogen prior to use. Commercially available reagents were used as supplied, whereas $\mathrm{WCl}_{4}(=0),{ }^{16} \mathrm{WCl}_{4}(=\mathrm{NPh})\left(\mathrm{OEt}_{2}\right),{ }^{9}\left[\mathrm{WCl}_{4}\right.$ $\left.(=\mathrm{NPh})\left(\mathrm{OCMe}_{3}\right)\right]\left[\mathrm{NEt}_{4}\right],{ }^{9} \quad \mathrm{WCl}_{3}(=\mathrm{NPh})\left(\mathrm{OC}_{6} \mathrm{H}_{3} \mathrm{Me}_{2}-\right.$ $3,5)\left(\mathrm{OEt}_{2}\right),{ }^{17} \mathrm{WCl}_{3}(=\mathrm{NPh})\left(\mathrm{OC}_{6} \mathrm{H}_{3} \mathrm{Me}_{2}-2,6\right)\left(\mathrm{OEt}_{2}\right),{ }^{17} \mathrm{Zn}$ $\left(\mathrm{CH}_{2} \mathrm{SiMe}_{3}\right)_{2},{ }^{18}$ and $\mathrm{Li}\left(\mathrm{C}_{6} \mathrm{H}_{4} \mathrm{CH}_{2} \mathrm{NMe}_{2}-2\right)^{19}$ were synthesized following literature procedures. ${ }^{1} \mathrm{H}$ and ${ }^{13} \mathrm{C}$ NMR spectra were recorded on a Bruker AC 300 spectrometer in benzene- $d_{6}$ at $25^{\circ} \mathrm{C}$; low temperature experiments were performed in toluene- $d_{8}$. Elemental analyses were carried out by the Mikroanalytisches Laboratorium Dornis und Kolbe, Mülheim a.d. Ruhr, Germany.

$\mathrm{W}\left(\mathrm{CH}_{2} \mathrm{SiMe}_{2}\right)_{3} \mathrm{Cl}(=\mathrm{NPh})$ (1). This complex was prepared via a modified literature procedure. ${ }^{9}$ Vacuum dried $\mathrm{Et}_{4} \mathrm{NCl}(1.5 \mathrm{~g}, 8.7 \mathrm{mmol})$ was added as a solid to a stirred solution of $\mathrm{WCl}_{4}(=\mathrm{NPh})\left(\mathrm{OEt}_{2}\right)(4.3 \mathrm{~g}, 8.7 \mathrm{mmol})$ in $\mathrm{CH}_{2} \mathrm{Cl}_{2}(50 \mathrm{~mL})$. After $15 \mathrm{~min}$ a solution of $\mathrm{Zn}\left(\mathrm{CH}_{2^{-}}\right.$ $\left.\mathrm{SiMe}_{3}\right)_{2}(3.2 \mathrm{~g}, 13.1 \mathrm{mmol})$ in $\mathrm{CH}_{2} \mathrm{Cl}_{2}(20 \mathrm{~mL})$ was added dropwise over a period of $10 \mathrm{~min}$. During addition the color of the reaction mixture changes from green to beige. This mixture was stirred for $1 \mathrm{~h}$, after which the volatiles were removed in vacuo leaving a beige solid. This solid was extracted with pentane $(2 \times 50 \mathrm{~mL})$. The combined pentane fractions were evaporated to dryness leaving 1 as a yellow/brown solid (in $90 \%$ yield) which was pure by ${ }^{1} \mathrm{H}$ NMR. ${ }^{9}$

$\mathrm{W}\left(\mathrm{CH}_{2} \mathrm{SiMe}_{3}\right)_{2} \mathrm{Cl}(=\mathrm{NPh})\left(\mathrm{OCMe}_{3}\right)(2)$. This complex was prepared via a procedure similar to the one described for the bis(neopentyl) analog. ${ }^{9} \mathrm{Zn}\left(\mathrm{CH}_{2} \mathrm{SiMe}_{3}\right)_{2}(5.78 \mathrm{~g}$, $24.1 \mathrm{mmol})$ in $\mathrm{CH}_{2} \mathrm{Cl}_{2}(15 \mathrm{~mL})$ was added slowly to a vigorously stirred solution of $\left[\mathrm{WCl}_{4}(=\mathrm{NPh})\right.$ $\left.\left(\mathrm{OCMe}_{3}\right)\right]\left[\mathrm{NEt}_{4}\right](14.96 \mathrm{~g}, 24.1 \mathrm{mmol})$ in $\mathrm{CH}_{2} \mathrm{Cl}_{2}(60 \mathrm{~mL})$. The volatiles were removed in vacuo, leaving a brown solid. After extraction with warm hexane $(2 \times 50 \mathrm{~mL})$, the crude product was obtained as a light-brown solid. Further

(16) Gibson, V. C.; Kee, T. P.; Shaw, A. Polyhedron 1988, 7, 579.

(17) van der Schaaf, P. A.; Boersma, J.; Smeets, W. J. J.; Spek, A. L.; van Koten, G. Inorg. Chem., in press.

(18) $\mathrm{Zn}\left(\mathrm{CH}_{2} \mathrm{SiMe}_{3}\right)_{2}$ was prepared from $\mathrm{LiCH}_{2} \mathrm{SiMe}_{3}$ and $\mathrm{ZnCl}_{2}$ in

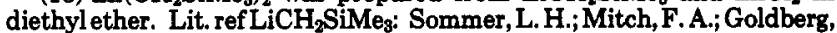
G. M. J. Am. Chem. Soc. 1949, 71, 2746.

(19) Jastrzebski, J. T. B. H.; van Koten, G. Inorg. Synth. 1989, 26, 150. 
purification by crystallization by cooling a saturated pentane solution to $-30^{\circ} \mathrm{C}$ affords 2 as a yellow solid (11.4 g, 85\%). ${ }^{1} \mathrm{H}$ NMR: $\delta 7.25\left(\mathrm{~d}, 2,{ }^{3} J_{\mathrm{H}_{o} \mathrm{H}_{m}}=7.8 \mathrm{~Hz}, 0-\mathrm{H}\right.$ $\mathrm{NPh}), 7.13\left(\mathrm{t}, 1, J_{\text {obsd }}=8.1 \mathrm{~Hz}, m-\mathrm{H} \mathrm{NPh}\right), 6.85(\mathrm{t}, 1$, $\left.{ }^{3} J_{\mathrm{H}_{p} \mathrm{H}_{m}}=7.5 \mathrm{~Hz}, p-\mathrm{H} \mathrm{NPh}\right), 2.80\left(\mathrm{~d}, 2,{ }^{2} J_{\mathrm{H}_{\mathrm{A}} \mathrm{H}_{\mathrm{B}}}=8.1 \mathrm{~Hz}\right.$, $\left.{ }^{2} J_{\mathrm{WH}}=9.1 \mathrm{~Hz}, \mathrm{CH}_{\mathrm{A}} \mathrm{H}_{\mathrm{B}} \mathrm{Si}\right), 2.13\left(\mathrm{~d}, 2,{ }^{2} J_{\mathrm{H}_{\mathrm{B}} \mathrm{H}_{\mathrm{A}}}=8.1 \mathrm{~Hz}\right.$, $\left.{ }^{2} J_{\mathrm{WH}}=8.8 \mathrm{~Hz}, \mathrm{CH}_{\mathrm{A}} H_{B} \mathrm{Si}\right), 1.23\left(\mathrm{~s}, 9, \mathrm{OCMe}_{3}\right), 0.24(\mathrm{~s}, 18$, $\left.\mathrm{SiMe}_{3}\right) .{ }^{13} \mathrm{C} \mathrm{NMR:} \delta 153.0\left(\mathrm{C}_{i p s o} \mathrm{NPh}\right) ; 128.8,127.6,126.4$ $(\mathrm{NPh}) ; 87.6\left(\mathrm{OCMe}_{3}\right) ; 70.1\left({ }^{1} J_{\mathrm{WC}}=79.5 \mathrm{~Hz}, \mathrm{CH}_{2} \mathrm{Si}\right) ; 31.4$ $\left(\mathrm{OCMe}_{3}\right) ; 2.5 \quad\left(\mathrm{SiMe}_{3}\right)$. Anal. Calcd for $\mathrm{C}_{18} \mathrm{H}_{36^{-}}$ ClNOSi ${ }_{2} \mathrm{~W}$ : C, 38.75; H, 6.50; N, 2.51. Found: C, 38.84; $\mathrm{H}, 6.59 ; \mathrm{N}, 2.56$.

$\mathrm{W}\left(\mathrm{CH}_{2} \mathrm{SiMe}_{3}\right)_{2} \mathrm{Cl}(=\mathrm{NPh})\left(\mathrm{OC}_{6} \mathrm{H}_{3} \mathrm{Me}_{2}-3,5\right)(3)$. This product was prepared via a modified procedure of that described for 2 . $\mathrm{Et}_{4} \mathrm{NCl}(3.10 \mathrm{~g}, 18.7 \mathrm{mmol})$ was added as a solid to a solution of $\mathrm{WCl}_{3}(=\mathrm{NPh})\left(\mathrm{OC}_{6} \mathrm{H}_{3} \mathrm{Me}_{2}-3,5\right)\left(\mathrm{OEt}_{2}\right)$ $(10.60 \mathrm{~g}, 18.4 \mathrm{mmol})$ in $\mathrm{CH}_{2} \mathrm{Cl}_{2}(50 \mathrm{~mL})$. After $10 \mathrm{~min}$ the reaction mixture was cooled to $0^{\circ} \mathrm{C}$ and a solution of $\mathrm{Zn}$ $\left(\mathrm{CH}_{2} \mathrm{SiMe}_{3}\right)_{2}(4.47 \mathrm{~g}, 18.4 \mathrm{mmol})$ in $10 \mathrm{~mL}$ of $\mathrm{CH}_{2} \mathrm{Cl}_{2}$ was added dropwise. After addition the reddish reaction mixture was stirred overnight at room temperature. The volatiles were removed in vacuo, and the residue was extracted with hexane $(3 \times 40 \mathrm{~mL})$. The combined hexane fractions were evaporated to dryness, leaving 3 as a brownish solid in $89 \%$ yield $(9.92 \mathrm{~g})$. ${ }^{1} \mathrm{H}$ NMR: $\delta 7.00$ 6.91 (m, 4, Ar H), 6.80 (t, 1, p-H NPh), 6.69 (s, 2, o-H OAr), $6.45(\mathrm{~s}, 1, p-\mathrm{H} \mathrm{OAr}), 2.77\left(\mathrm{~d}, 2,{ }^{2} J_{\mathrm{H}_{\mathrm{A}} \mathrm{H}_{\mathrm{B}}}=7.7 \mathrm{~Hz},{ }^{2} J_{\mathrm{WH}}=\right.$ $\left.9.4 \mathrm{~Hz}, \mathrm{CH}_{A} \mathrm{H}_{\mathrm{B}} \mathrm{Si}\right), 2.48\left(\mathrm{~d}, 2,{ }^{2} J_{\mathrm{H}_{\mathrm{B}} \mathrm{H}_{\mathrm{A}}}=7.7 \mathrm{~Hz},{ }^{2} J_{\mathrm{WH}}=9.4\right.$ $\left.\mathrm{Hz}, \mathrm{CH}_{\mathrm{A}} H_{B} \mathrm{Si}\right), 2.00$ (s, 6, $\left.\mathrm{Me}_{2}-3,5\right), 0.23$ (s, 18, $\mathrm{SiMe}_{3}$ ). ${ }^{13} \mathrm{C}$ NMR: $\delta 166.9\left(\mathrm{C}_{i p s o} \mathrm{OAr}\right) ; 151.4\left(\mathrm{C}_{i p s o} \mathrm{NPh}\right) ; 139.6,128.7-$ $127.1,125.5,118.1,117.4(\mathrm{Ar} \mathrm{C}) ; 75.9\left({ }^{1} J_{\mathrm{WC}}=81.5 \mathrm{~Hz}\right.$, $\left.\mathrm{CH}_{2} \mathrm{Si}\right) ; 21.1\left(\mathrm{Me}_{2}-3,5\right) ; 2.1\left(\mathrm{SiMe}_{3}\right)$. Anal. Calcd for $\mathrm{C}_{22} \mathrm{H}_{36} \mathrm{ClNOSi}_{2} \mathrm{~W}: \mathrm{C}, 43.60 ; \mathrm{H}, 5.99 ; \mathrm{N}, 2.31$. Found: C, 43.48; H, 6.05; N, 2.42.

$\mathrm{W}\left(\mathrm{CH}_{2} \mathrm{SiMe}_{3}\right)_{2} \mathrm{Cl}(=\mathrm{NPh})\left(\mathrm{OC}_{6} \mathrm{H}_{3} \mathrm{Me}_{2}-2,6\right)$ (4). This complex was prepared via the procedure described for 3 . Starting from $\mathrm{WCl}_{3}(=\mathrm{NPh})\left(\mathrm{OC}_{6} \mathrm{H}_{3} \mathrm{Me}_{2}-2,6\right)\left(\mathrm{OEt}_{2}\right)(9.62$ $\mathrm{g}, 16.7 \mathrm{mmol}), 1$ equiv of $\mathrm{Et}_{4} \mathrm{NCl}$, and $\mathrm{Zn}\left(\mathrm{CH}_{2} \mathrm{SiMe}_{3}\right)_{2}(4.00$ g), this method yields 4 as a dark-red, spongy solid in $91 \%$ yield $(9.21 \mathrm{~g}) .{ }^{1} \mathrm{H}$ NMR: $\delta 6.93-6.68(\mathrm{~m}, 8, \mathrm{Ar} \mathrm{H}), 2.90(\mathrm{~d}$, $\left.2,{ }^{2} J_{\mathrm{H}_{\mathrm{A}} \mathrm{H}_{\mathrm{B}}}=8.0 \mathrm{~Hz},{ }^{2} J_{\mathrm{WH}}=9.5 \mathrm{~Hz}, \mathrm{CH}_{\mathrm{A}} \mathrm{H}_{\mathrm{B}} \mathrm{Si}\right), 2.33(\mathrm{~d}, 2$, $\left.{ }^{2} J_{\mathrm{H}_{\mathrm{B}} \mathrm{H}_{\mathrm{A}}}=8.0 \mathrm{~Hz},{ }^{2} J_{\mathrm{WH}}=9.3 \mathrm{~Hz}, \mathrm{CH}_{\mathrm{A}} H_{B} \mathrm{Si}\right), 2.24(\mathrm{~s}, 6$, $\left.\mathrm{Me}_{2}-2,6\right), 0.25$ (s, 18, $\left.\mathrm{SiMe}_{3}\right) .{ }^{13} \mathrm{C} \mathrm{NMR}$ : $\delta 166.9\left(\mathrm{C}_{\text {ipso }}\right.$ OAr); $151.4\left(\mathrm{C}_{\text {ipso }} \mathrm{NPh}\right) ; 139.1,129.7,128.8-127.1,125.6$, $117.3(\mathrm{Ar}-\mathrm{C}) ; 75.9\left({ }^{1} J_{\mathrm{WC}}=81.8 \mathrm{~Hz}, \mathrm{CH}_{2} \mathrm{Si}\right) ; 21.2\left(\mathrm{Me}_{2}-\right.$ 2,6); $2.4\left(\mathrm{SiMe}_{3}\right)$.

$\mathrm{W}\left(\mathrm{C}_{6} \mathrm{H}_{4} \mathrm{CH}_{2} \mathrm{NMe}_{2}-2\right)(=\mathrm{CHSiMe})\left(\mathrm{CH}_{2} \mathrm{SiMe}_{3}\right)-$ $(=\mathrm{NPh})(5)$. A suspension of $\mathrm{Li}\left(\mathrm{C}_{6} \mathrm{H}_{4} \mathrm{CH}_{2} \mathrm{NMe}_{2}-2\right)(2.04$ g, $14.5 \mathrm{mmol})$ in $\mathrm{Et}_{2} \mathrm{O}(30 \mathrm{~mL})$ was added to a stirred solution of $\mathrm{W}\left(\mathrm{CH}_{2} \mathrm{SiMe}_{3}\right)_{3} \mathrm{Cl}(=\mathrm{NPh})(8.23 \mathrm{~g}, 14.4 \mathrm{mmol})$ in $\mathrm{Et}_{2} \mathrm{O}(60 \mathrm{~mL})$ at $-78^{\circ} \mathrm{C}$. The temperature of the reaction mixture was slowly raised to $25^{\circ} \mathrm{C}$ (within $1 \mathrm{~h}$ ). The red reaction mixture was stirred for an additional $1 \mathrm{~h}$. The solvent was removed in vacuo, leaving a sticky red-brown oil. The product was analytically pure after recrystallization from a pentane solution. Yield: $5.88 \mathrm{~g}(70 \%) .{ }^{1} \mathrm{H}$ NMR: $\delta 8.41(\mathrm{~d}, 1 \mathrm{H}, o-\mathrm{H}), 8.25\left(\mathrm{~s}, 1 \mathrm{H},{ }^{2} J_{\mathrm{WH}}=10.3 \mathrm{~Hz}\right.$, $\mathrm{H}_{\alpha}$ ), 7.56-7.07 (m, 7H, Ar H), $6.94(\mathrm{t}, 1 \mathrm{H}, p-\mathrm{H} \mathrm{NPh}), 3.98$ (d, $\left.1 \mathrm{H},{ }^{2} J_{\mathrm{H}_{\mathrm{A}} \mathrm{H}_{\mathrm{B}}}=12.6 \mathrm{~Hz}, \mathrm{CH}_{A} \mathrm{H}_{\mathrm{B}} \mathrm{N}\right), 3.32\left(\mathrm{~d}, 1 \mathrm{H},{ }^{2} J_{\mathrm{H}_{\mathrm{B}} \mathrm{H}_{\mathrm{A}}}\right.$ $\left.=12.6 \mathrm{~Hz}, \mathrm{CH}_{\mathrm{A}} H_{B} \mathrm{~N}\right), 2.45$ and $1.59(2 \mathrm{~s}, 6 \mathrm{H}, \mathrm{NMe}), 0.57$ (d, $1 \mathrm{H},{ }^{2} J_{\mathrm{H}_{\mathrm{A}} \mathrm{H}_{\mathrm{B}}}=11.9 \mathrm{~Hz},{ }^{2} J_{\mathrm{WH}}=8.0 \mathrm{~Hz}, \mathrm{CH}_{\mathrm{A}} \mathrm{H}_{\mathrm{B}} \mathrm{Si}$ ), 0.33 and $0.27\left(2 \mathrm{~s}, 18 \mathrm{H}, \mathrm{SiMe}_{3}\right), 0.02\left(\mathrm{~d}, 1 \mathrm{H},{ }^{2} J_{\mathrm{H}_{\mathrm{B}} \mathrm{H}_{\mathrm{A}}}=11.9 \mathrm{~Hz}\right.$, $\left.{ }^{2} J_{\mathrm{WH}}=8.0 \mathrm{~Hz}, \mathrm{CH}_{\mathrm{A}} H_{B} \mathrm{Si}\right) .{ }^{13} \mathrm{C}$ NMR: $\delta 236.1\left({ }^{1} J_{\mathrm{WC}}=\right.$ $\left.133.0 \mathrm{~Hz},{ }^{1} J_{\mathrm{CH}}=109.6 \mathrm{~Hz}, \mathrm{CHSi}\right) ; 190.0\left(\mathrm{C}_{i p s o},{ }^{1} J_{\mathrm{WC}}=\right.$ $109.3 \mathrm{~Hz}) ; 156.6\left(\mathrm{C}_{i p s o} \mathrm{NPh}\right) ; 149.1,144.0,128.8-123.2(\mathrm{Ar}$
C); $75.1\left(\mathrm{CH}_{2} \mathrm{~N}\right) ; 49.3$ and $45.8(2 \times \mathrm{NMe}) ; 49.1\left(\mathrm{CH}_{2} \mathrm{Si}\right.$, $\left.{ }^{1} J_{\mathrm{WC}}=70.1 \mathrm{~Hz}\right) ; 3.0$ and $2.7\left(2 \times \mathrm{SiMe}_{3}\right)$. Anal. Calcd for $\mathrm{C}_{23} \mathrm{H}_{38} \mathrm{~N}_{2} \mathrm{Si}_{2} \mathrm{~W}$ : C, $47.42 ; \mathrm{H}, 6.57 ; \mathrm{N}, 4.81$. Found: $\mathrm{C}, 46.80$; $\mathrm{H}, 6.60 ; \mathrm{N}, 4.60$.

$\mathrm{W}\left(\mathrm{C}_{6} \mathrm{H}_{4} \mathrm{CH}_{2} \mathrm{NMe}_{2}-2\right)\left(=\mathrm{CHSiMe}_{3}\right)(=\mathrm{NPh})(\mathrm{OSi}-$ $\left.\mathrm{Ph}_{3}\right)$ (6). Triphenylsilanol $(0.88 \mathrm{~g}, 3.18 \mathrm{mmol})$ was added as a solid to a cooled solution of $5(1.84 \mathrm{~g}, 3.16 \mathrm{mmol})$ in pentane $\left(40 \mathrm{~mL}, 0^{\circ} \mathrm{C}\right)$. The reaction mixture was stirred for $2 \mathrm{~h}$ at $0^{\circ} \mathrm{C}$ and an additional $1 \mathrm{~h}$ at $25^{\circ} \mathrm{C}$. The volatiles were removed in vacuo. The resulting crude product, a yellow solid, was crystallized from a minimum of hexane. Yield: $1.62 \mathrm{~g}(67 \%) .{ }^{1} \mathrm{H}$ NMR: $\delta 10.09\left(\mathrm{~s}, 1 \mathrm{H},{ }^{2} J_{\mathrm{WH}}=11.1\right.$ $\left.\mathrm{Hz}, \mathrm{H}_{\alpha}\right), 8.62(\mathrm{~d}, 1 \mathrm{H}, o-\mathrm{H}), 7.81\left(\mathrm{~m}, 6 \mathrm{H}, o-\mathrm{H} \mathrm{SiPh}_{3}\right), 7.19-$ $6.96(\mathrm{~m}, 16 \mathrm{H}, \mathrm{Ar} \mathrm{H}), 6.82(\mathrm{t}, 1 \mathrm{H}, p-\mathrm{H} \mathrm{NPh}), 3.78(\mathrm{~d}, 1 \mathrm{H}$, $\left.{ }^{2} J_{\mathrm{H}_{\mathrm{A}} \mathrm{H}_{\mathrm{B}}}=12.7 \mathrm{~Hz}, \mathrm{CH}_{\mathrm{A}} \mathrm{H}_{\mathrm{B}} \mathrm{N}\right), 3.19\left(\mathrm{~d}, 1 \mathrm{H},{ }^{2} J_{\mathrm{H}_{\mathrm{B}} \mathrm{H}_{\mathrm{A}}}=12.7\right.$ $\left.\mathrm{Hz}, \mathrm{CH}_{\mathrm{A}} H_{B} \mathrm{~N}\right), 2.46$ and $1.85(2 \mathrm{~s}, 6 \mathrm{H}, \mathrm{NMe}), 0.32(\mathrm{~s}, 9 \mathrm{H}$, $\left.\mathrm{SiMe}_{3}\right) .{ }^{13} \mathrm{C} \mathrm{NMR:} \delta 238.0\left({ }^{1} J_{\mathrm{WC}}=139.0 \mathrm{~Hz},{ }^{1} J_{\mathrm{CH}}=113.9\right.$ $\mathrm{Hz}, \mathrm{CHSi}) ; 182.0\left(\mathrm{C}_{i p s o},{ }^{1} J_{\mathrm{WC}}=128.5 \mathrm{~Hz}\right) ; 155.8\left(\mathrm{C}_{i p s o} \mathrm{NPh}\right)$; 148.7, 144.0, 137.7, 136.4, 135.9, 129.9-123.9 (Ar C); 71.2 $\left(\mathrm{CH}_{2} \mathrm{~N}\right) ; 48.4$ and $45.7(2 \times \mathrm{NMe}) ; 2.9\left(\mathrm{SiMe}_{3}\right)$. Anal. Calcd for $\mathrm{C}_{37} \mathrm{H}_{42} \mathrm{~N}_{2} \mathrm{OSi}_{2} \mathrm{~W}$ : C, 57.66; $\mathrm{H}, 5.49 ; \mathrm{N}, 3.63$. Found: C, 57.48; H, 5.61; N, 3.78 .

$\mathrm{W}\left(\mathrm{C}_{6} \mathrm{H}_{4} \mathrm{CH}_{2} \mathrm{NMe}_{2}-2\right)\left(\mathrm{CH}_{2} \mathrm{SiMe}_{3}\right)_{2}(=\mathrm{NPh})(\mathrm{OC}-$ $\left.\mathrm{Me}_{3}\right)$ (7). This complex was prepared via a procedure similar to the one described for 5 . The reaction of $\mathrm{Li}$ $\left(\mathrm{C}_{6} \mathrm{H}_{4} \mathrm{CH}_{2} \mathrm{NMe}_{2}-2\right)(1.12 \mathrm{~g}, 7.93 \mathrm{mmol})$ in $\mathrm{Et}_{2} \mathrm{O}(20 \mathrm{~mL})$ and $2(4.41 \mathrm{~g}, 7.90 \mathrm{mmol})$ in $\mathrm{Et}_{2} \mathrm{O}(60 \mathrm{~mL})$ at $-78^{\circ} \mathrm{C}$ affords, after recrystallization from a minimum of hexane, $4.1 \mathrm{~g}$ of $7(78 \%)$ as orange-red crystals. Complex 7 can also be prepared by reacting 5 with an equimolar amount of tertbutyl alcohol via a procedure similar to that described for 6. The purification procedure, however, was hampered by the presence of some unidentified side products. ${ }^{1} \mathrm{H}$ NMR data of a sample prepared at $-80^{\circ} \mathrm{C}$ (denoted 7a) (toluene- $\left.d_{8},-70^{\circ} \mathrm{C}\right): \delta 8.48(\mathrm{~d}, 1 \mathrm{H}, o-\mathrm{H}), 7.70(\mathrm{~d}, 2 \mathrm{H}, o-\mathrm{H}$ $\mathrm{NPh}), 7.41-7.00(\mathrm{Ar} \mathrm{H}), 6.71(\mathrm{t}, 1 \mathrm{H}, p-\mathrm{NPh}), 4.10(\mathrm{~d}, 1 \mathrm{H}$, $\left.{ }^{2} J_{\mathrm{H}_{\mathrm{A}} \mathrm{H}_{\mathrm{B}}}=13.3 \mathrm{~Hz}, \mathrm{CH}_{A} \mathrm{H}_{\mathrm{B}} \mathrm{N}\right), 2.85\left(\mathrm{~d}, 1 \mathrm{H},{ }^{2} J_{\mathrm{H}_{\mathrm{B}} \mathrm{H}_{\mathrm{A}}}=13.5\right.$ $\left.\mathrm{Hz}, \mathrm{CH}_{\mathrm{A}} H_{B} \mathrm{~N}\right), 2.12$ and $2.10(2 \mathrm{~s}, 6 \mathrm{H}, \mathrm{NMe}), 1.96(\mathrm{~d}, 1 \mathrm{H}$, ${ }^{2} J_{\mathrm{H}_{\mathrm{A}} \mathrm{H}_{\mathrm{B}}}=13.7 \mathrm{~Hz}, \mathrm{C} H_{A} \mathrm{H}_{\mathrm{B}} \mathrm{Si}\left(\mathrm{H}_{\mathrm{B}}\right.$ signal hidden under $\mathrm{OCMe}_{3}$ signal)), $1.02\left(\mathrm{~s}, 9, \mathrm{OCMe}_{3}\right), 0.75\left(\mathrm{~d}, 1 \mathrm{H},{ }^{2} J_{\mathrm{H}_{\mathrm{A}} \mathrm{H}_{\mathrm{B}}}=\right.$ $13.8 \mathrm{~Hz}, \mathrm{CH}_{A} \mathrm{H}_{\mathrm{B}} \mathrm{Si}$ ), 0.48 and $0.47\left(\mathrm{SiMe}_{3}\right), 0.35$ (d, $1 \mathrm{H}$, $\left.{ }^{2} J_{\mathrm{H}_{\mathrm{B}} \mathrm{H}_{\mathrm{A}}}=13.8 \mathrm{~Hz}, \mathrm{CH}_{\mathrm{A}} H_{B} \mathrm{Si}\right)$. When a NMR sample is prepared at $25^{\circ} \mathrm{C}$ a complex spectrum is obtained in which three different species, 7a, 7b, and $\mathbf{7 c}$, are present. Selected ${ }^{1} \mathrm{H}$ NMR data: $(o-\mathrm{H}) \delta 8.48,8.20,7.51 ;\left(\mathrm{CH}_{2} \mathrm{~N}\right) \delta 4.12,3.15$ $\left(\mathrm{dd},{ }^{3} J_{\mathrm{HH}}=13.4 \mathrm{~Hz}\right), 3.58(\mathrm{~s}), 3.30(\mathrm{~s}) ;\left(\mathrm{SiMe}_{3}\right) \delta 0.38$ and 0.27 (2s), 0.32 (s), 0.06 (s). Anal. Calcd for $\mathrm{C}_{27} \mathrm{H}_{48} \mathrm{~N}_{2-}$ $\mathrm{OSi}_{2} \mathrm{~W}: \mathrm{C}, 49.38 ; \mathrm{H}, 7.37 ; \mathrm{N}, 4.27 ; \mathrm{Si}, 8.58$. Found: C, 49.04; H, 7.34; N, 4.49; Si, 9.02. Molecular weight determination by cryoscopy $(0.16$ and $0.45 \mathrm{~g}$ in $16.70 \mathrm{~g}$ of benzene): calcd for monomer, 656.7 ; found, 635 and 660 (degree of assocation: 1.05 and 1.00).

$\mathrm{W}\left(\mathrm{C}_{6} \mathrm{H}_{4} \mathrm{CH}_{2} \mathrm{NMe}_{2}-2\right)\left(=\mathrm{CHSiMe}_{3}\right)(=\mathrm{NPh})(\mathrm{OC}-$ $\left.\mathrm{Me}_{3}\right)(8)$. A solution of $7(1.52 \mathrm{~g})$ in hexane $(15 \mathrm{~mL})$ was heated at reflux for $8 \mathrm{~h}$. Every hour a sample was taken from the reaction mixture and dried in vacuo. The residue was dissolved in $\mathrm{C}_{6} \mathrm{D}_{6}$, and an NMR spectrum was recorded. It appeared that 8 was readily formed. However, it decomposed during the time of reflux. Complex 8 could not be obtained pure. Characteristic ${ }^{1} \mathrm{H}$ NMR data: $\delta$ $9.82\left(\mathrm{H}_{\alpha},{ }^{2} J_{\mathrm{WH}}\right.$ not obsd), $0.18\left(\mathrm{SiMe}_{3}\right)$.

$\mathrm{W}\left(\mathrm{C}_{6} \mathrm{H}_{4} \mathrm{CH}_{2} \mathrm{NMe}_{2}-2\right)\left(\mathrm{CH}_{2} \mathrm{SiMe}_{3}\right)_{2}(=\mathrm{NPh})\left(\mathrm{OC}_{6} \mathrm{H}_{3}\right.$ $\left.\mathrm{Me}_{2}-\mathbf{3 , 5}\right)(9)$. This complex was prepared via a procedure similar to the one described for 6 . Starting from $4(6.08$ $\mathrm{g}, 10.0 \mathrm{mmol})$ and $\mathrm{Li}\left(\mathrm{C}_{6} \mathrm{H}_{4} \mathrm{CH}_{2} \mathrm{NMe}_{2}-2\right)(1.46 \mathrm{~g}, 10.3 \mathrm{mmol})$, 
this procedure affords 9 , after recrystallization by cooling a saturated hexane solution, as yellow needles $(5.99 \mathrm{~g}) .{ }^{1} \mathrm{H}$ NMR: $\delta 7.81$ (m, 1, o-H Ar), 7.27-7.05 (m, 7, Ar H), 6.82 (t, 1, p-H NPh), 6.43 (s, 1, p-H OAr), 6.32 (s, 2, o-H OAr), 3.52 (br s, 2, $\mathrm{CH}_{2} \mathrm{~N}$ ), 2.26 (sharp $\mathrm{AB}$ pattern, 2, $\mathrm{CH}_{2} \mathrm{Si}$ ), 2.13 (s, 6, $\mathrm{NMe}_{2}$ ), 2.02 (s, 6, $\left.\mathrm{Me}_{2}-2,6\right), 1.40$ (s, 2, $\left.\mathrm{CH}_{2} \mathrm{Si}\right)$, $0.24\left(\mathrm{~s}, 18, \mathrm{SiMe}_{3}\right)$. ${ }^{13} \mathrm{C} \mathrm{NMR}: \delta 188.9\left(\mathrm{C}_{i p s o} \mathrm{Ar},{ }^{1} J_{\mathrm{WC}}=\right.$ $105.5 \mathrm{~Hz}) ; 164.2\left(\mathrm{C}_{i p s o} \mathrm{OAr}\right), 155.0\left(\mathrm{C}_{i p s o} \mathrm{NPh}\right) ; 145.9,138.7$, 136.0, 128.5-127.3, 126.2, 125.8, 125.0, 121.3, 117.2 (Ar C); $70.4\left(\mathrm{CH}_{2} \mathrm{~N}\right) ; 69.6\left(\right.$ broad $\left.\mathrm{CH}_{2} \mathrm{Si},{ }^{1} J_{\mathrm{WC}}=83.5 \mathrm{~Hz}\right) ; 47.6$ $\left(\mathrm{NMe}_{2}\right) ; 21.6\left(\mathrm{Me}_{2}-2,6\right) ; 2.8\left(\mathrm{SiMe}_{3}\right) .{ }^{1} \mathrm{H} \mathrm{NMR}$ at $-30^{\circ} \mathrm{C}$ : $\delta$ Ar $\mathrm{H}$ unchanged; $2.13,1.95\left(\mathrm{dd}, 2, \mathrm{CH}_{2} \mathrm{~N},{ }^{2} J_{\mathrm{HH}}=12.4\right.$ $\mathrm{Hz}$; $2.61,0.18\left(\mathrm{dd}, 2, \mathrm{CH}_{2} \mathrm{Si},{ }^{2} J_{\mathrm{HH}}=12.2 \mathrm{~Hz}\right) ; 2.32,2.22$ (dd, $\left.2, \mathrm{CH}_{2} \mathrm{Si},{ }^{2} \mathrm{~J}_{\mathrm{HH}}=15.6 \mathrm{~Hz}\right) ; 2.14\left(\mathrm{~s}, 6, \mathrm{Me}_{2}-3,5\right) ; 2.13$ and $1.95\left(2 \mathrm{~s}, 6, \mathrm{NMe}_{2}\right) ; 0.29,0.25\left(2 \mathrm{~s}, \mathrm{SiMe}_{3}\right)$. Anal. Calcd for $\mathrm{C}_{31} \mathrm{H}_{48} \mathrm{~N}_{2} \mathrm{OSi}_{2} \mathrm{~W}$ : C, 52.83; H, 6.87; N, 3.97. Found: C, 52.82; H, 6.81; N, 4.07.

Polymerization Reactions. In a typical experiment $1 \mathrm{~mL}$ of a $0.05 \mathrm{M}$ solution of 5 in benzene was added via a syringe to a vigorously stirred solution $(10 \mathrm{~mL}, 1.0 \mathrm{M})$ of norbornene in benzene ( 200 equiv) at room temperature. The viscosity of this reaction mixture increased after a few seconds. After 10 min a drop of benzaldehyde was added and the mixture was poured into ethanol. The polymer was collected by filtration and dried in vacuo (quantitative yield). A piece of this polymer was redissolved in $\mathrm{C}_{6} \mathrm{D}_{6}$ (in one night) for NMR measurements. The signals were in accord with those reported for polynorbornene in the literature, ${ }^{14}$ and no other signals were observed. The polymer contained $>90 \%$ cis-vinylene hydrogens.

X-ray Structure Determination of $\mathbf{W}\left(\mathrm{C}_{6} \mathrm{H}_{4} \mathrm{CH}_{2-}\right.$ $\left.\mathrm{NMe}_{2}-2\right)\left(=\mathrm{CHSiMe}_{3}\right)\left(\mathrm{CH}_{2} \mathrm{SiMe}_{3}\right)(=\mathrm{NPh})$ (5). Numerical data on the structure determination have been collected in Table V. X-ray data were collected at $100 \mathrm{~K}$ on an Enraf-Nonius CAD4 diffractometer. The best crystal available was of relatively poor quality, as indicated by structured reflection profiles. Unit-cell parameters were derived from the SET4 setting angles of 25 reflections $\left(9<\theta<16^{\circ}\right)$. Intensity data were corrected for $L p$, a small linear decay of $3 \%$, and absorption [DIFABS, ${ }^{20}$ correction range $0.79: 1.21$ ]. The structure was solved by standard Patterson and difference Fourier techniques [SHELXS86 ${ }^{21}$ ] and refined on $F$ by full matrix least squares with SHELX76.22 W, Si, and $\mathrm{M}$ were refined with anisotropic thermal parameters; $C$ atoms were refined isotropically in view of the quality of the data set. Hydrogen atoms were taken into account at calculated

(20) Walker, N.; Stuart, D. Acta Crystallogr. 1983, A39, 158.

(21) Sheldrick, G. M. SHELXS86. Program for crystal structure determination; University of Göttingen: Göttingen, Federal Republic of Germany, 1986.

(22) Sheldrick, G. M. SHELX76. Crystal structure analysis package; University of Cambridge: Cambridge, England, 1976.
Table V. Crystal Data and Details of the Structure Determination of Complex 5

\begin{tabular}{|c|c|}
\hline \multicolumn{2}{|c|}{ Crystal Data } \\
\hline $\begin{array}{l}\text { formula } \\
\text { mol wt } \\
\text { cryst syst } \\
\text { space group } \\
a, b, c(\AA) \\
\beta(\text { deg }) \\
V\left(\AA^{3}\right) \\
Z \\
D_{\text {calc }}\left(\mathrm{g} \mathrm{cm}^{-3}\right) \\
F(000) \\
\mu\left(\mathrm{cm}^{-1}\right) \\
\text { cryst size }(\mathrm{mm})\end{array}$ & $\begin{array}{l}\mathrm{WC}_{23} \mathrm{H}_{38} \mathrm{~N}_{2} \mathrm{Si}_{2} \\
582.59 \\
\text { monoclinic } \\
P 2_{1} / a(\mathrm{No} .14) \\
17.950(3), 16.633(4), 19.472(4) \\
115.48(2) \\
5248(2) \\
8 \\
1.475 \\
2336 \\
46.0 \\
0.50 \times 0.25 \times 0.12\end{array}$ \\
\hline $\begin{array}{l}\text { temp }(\mathrm{K}) \\
\theta_{\min }, \theta_{\max }(\mathrm{deg}) \\
\text { radiation, } \lambda(\AA) \\
\Delta \omega(\text { deg) } \\
\text { hor, vert aperture (mm) } \\
\text { linear decay }(\%) \\
\text { ref refl } \\
\text { data set } \\
\text { total no. of and no. of unique data } \\
\text { no. of obsd data }[I>2.5 \sigma(I)]\end{array}$ & $\begin{array}{l}\text { ection } \\
100 \\
1.16,27.5 \\
\text { Mo } K \alpha ; 0.71073 \\
0.75+0.35 \tan \theta \\
3.00,5.00 \\
3 \\
-2,0,2 ;-2,2,0 ; 0,-2,2 \\
-23: 0 ;-21: 0 ;-22: 25 \\
14368,12011 \\
5981\end{array}$ \\
\hline $\begin{array}{l}\text { no. of refined par } \\
\text { no. of refl } \\
\text { weighting scheme } \\
\text { final } R, R_{w} \\
\text { max, av shift/error } \\
\text { min, max resd dens }\left(e / \AA^{3}\right)\end{array}$ & $\begin{array}{l}\text { nent } \\
276 \\
5981 \\
1 / \sigma^{2}(F) \\
0.0661,0.0653 \\
0.0193,0.256 \\
-2.10,3.37\end{array}$ \\
\hline
\end{tabular}

positions with one common isotropic thermal parameter. Final positional parameters have been collected in Table I. Scattering factors were taken from ref 23 and corrected for anomalous dispersion. ${ }^{24}$ Geometrical calculations including Figure 2 (ORTEP) were done with PLATON..$^{25}$ Calculations were done on a DEC5000 cluster.

Acknowledgment. This work was supported in part (A.L.S., W.J.J.S., and P.A.v.d.S.) by the Netherlands Foundation for Chemical Research (SON) with financial aid from the Netherlands Organization for Science Research (NWO). The X-ray data were kindly collected by Mr. A. J. M. Duisenberg.

Supplementary Material Available: For 5, tables of crystal data and details of the structure determination, fractional coordinates of all atoms, bond distances and angles, and anisotropic thermal parameters (12 pages). Ordering information is given on any current masthead page.

\section{OM9302554}

(23) Cromer, D. T.; Mann, J. B. Acta Crystallogr, 1968, A24, 321

(24) Cromer, D. T.; Liberman, D. J. Chem. Phys. 1970, 53, 1891.

(25) Spek, A. L. Acta Crystallogr. 1990, A46, C34. 